Article

\title{
Optimisation and Modelling of Anaerobic Digestion of Whiskey Distillery/Brewery Wastes after Combined Chemical and Mechanical Pre-Treatment
}

\author{
Burcu Gunes ${ }^{1}$, Maxime Carrié ${ }^{1}{ }^{1}$, Khaled Benyounis ${ }^{2}$, Joseph Stokes ${ }^{2}$, Paul Davis ${ }^{3}$, \\ Cathal Connolly ${ }^{4}$ and Jenny Lawler ${ }^{1,5, *}$
}

1 School of Biotechnology and DCU Water Institute, Dublin City University, Dublin 9 Glasnevin, Ireland; burcu.gunes@dcu.ie (B.G.); maxime.carrie1@gmail.com (M.C.)

2 School of Mechanical \& Manufacturing Engineering, Dublin City University, Dublin 9 Glasnevin, Ireland; khaled.benyounis2@mail.dcu.ie (K.B.); joseph.t.stokes@dcu.ie (J.S.)

3 School of Business and DCU Water Institute, Dublin City University, Dublin 9 Glasnevin, Ireland; paul.davis@dcu.ie

4 Alltech European Bioscience Centre, Summerhill Road, Co. Meath Dunboyne, Ireland; cconnolly@alltech.com

5 Qatar Environment and Energy Research Institute (QEERI), Hamad Bin Khalifa University, Doha P.O. Box 34110, Qatar

* Correspondence: jlawler@hbku.edu.qa; Tel.: +974-445-48116

Received: 8 March 2020; Accepted: 29 March 2020; Published: 23 April 2020

\begin{abstract}
Whiskey distillery waste streams consisting of pot ale (liquid residue) and spent grain (solid residue) are high strength organic wastes and suitable feedstock for anaerobic digestion (AD) from both economic and environmental stand points. Anaerobic digestion of pot ale and pot ale/spent grain mixtures (with mixing ratios of 1:1,1:3, and 1:5 by wet weight) was performed after implementation of a novel hybrid pre-treatment (combined chemical and mechanical) in order to modify lignocellulosic structure and ultimately enhance digestion yield. Lignin, hemicellulose, and cellulose fractions were determined before and after chemical pre-treatment. Effects of different inoculum rates (10-30-50\% on wet basis) and beating times (0-7.5-15 $\mathrm{min}$ ) on anaerobic digestion of pot ale alone and of pot ale/spent grain mixtures were investigated in lab scale batch mode with a major focus of optimising biogas yield by using response surface methodology (RSM) in Design Expert Software. The highest biogas yields of $629 \pm 8.5 \mathrm{~mL} / \mathrm{g}$ vs. $\left(51.3 \% \mathrm{CH}_{4}\right)$ and $360 \pm 10 \mathrm{~mL} / \mathrm{g}$ vs. $(55.0 \pm 0.4)$ with anaerobic digestion of pot ale alone and spent grain mix after $1 \mathrm{M} \mathrm{NaOH}$ and $7.5 \mathrm{~min}$ beating pre-treatments with $50 \%$ inoculum ratio respectively. The optimum digestion conditions to maximise the biogas quality and quantity were predicted as 10 and $13 \mathrm{~min}$ beating times and 32 and $38{ }^{\circ} \mathrm{C}$ digestion temperatures for anaerobic digestion of pot ale alone and spent grain mix respectively.
\end{abstract}

Keywords: anaerobic digestion; pot ale; spent grain; pre-treatment; lignocellulose; response surface methodology

\section{Introduction}

Widespread usage of fossil fuels as non-renewable energy source has been targeted for reduction because of many ecological and environmental concerns for impact on climate conditions and human migration due to continuous greenhouse gas emissions such as $\mathrm{CO}_{2}[1,2]$. Therefore, the European Union aims to reduce the total greenhouse emissions to $80-95 \%$ of 1990 levels by 2050 in developed countries [3]. In addition, European Council Directive 999/31/EC aims to reduce landfilling of organic waste [4]. As a result of increasing energy demand as well as environmental concerns, exploration 
of alternative energy sources has arisen [5]. Among the renewable energy sources, biogas, which is methane rich gas produced by anaerobic digestion $(\mathrm{AD})$ of organic waste, is considered to be among the most environmentally friendly fuel sources [6] owing to its non-toxic characteristics and potential for simplicity of use as an alternative over traditional fossil fuels, as well as its potential reduction in wastes sent to landfill [7].

Typical waste disposal levels of whiskey distilleries and breweries and the potential environmental concerns associated with those waste streams was outlined by [8]. Due to the high organic content, large disposal volume, and the acidic nature, pot ale is the major concern of the waste management of whiskey distilleries. As such, AD with advantages over other waste management methods like low energy requirement, odour limitation, less by-product generation, and higher ability to cope with recalcitrant nature of whiskey distillery/brewery waste streams is a suitable alternative waste treatment method [9-12]. There are four main stages in the AD process-namely hydrolysis, acidogenesis, acetogenesis, and methanogenesis—and the reactions in each stage are carried out by different bacteria. The thermodynamics of each AD stage and potential bacterial competitions have been reported in detail by $[13,14]$. In order to have a balanced $A D$, identical reaction rates are desired, however, the hydrolysis step is considered to be the rate limiting step for the digestion of lignocellulosic matter due to the impact of high lignin content on mass transfer [5,15-17]. Although the impact of various pre-treatment technologies have been investigated on lignocellulosic materials - such as municipal organic waste [18], wheat straw and sugarcane bagasse [19], maple, oak and corn leaves and stalks [20], maize straw [21], corn stove [22], palm waste [23], lignocellulosic biomass [24], algal biomass [25] with an ultimate goal of achieving lignin solubilisation as well as reducing the crystal structure of cellulose to render readily degradable materials accessible to bacterial attack [26-28]-implementation of pre-treatment on whiskey distillery and brewery wastes and its impact on lignocellulose fractions have received scant attention in the literature [29].

Chemical pre-treatment is a well-studied and widely accepted method in AD for a variety of lignocellulosic feedstocks $[4,30]$. Alkaline pre-treatment with $\mathrm{NaOH}$ was suggested as an effective alkaline pre-treatment [31,32] due to its ability to disturb the lignin structure by breaking the link between lignin and the carbohydrate fractions in the biomass, hence rendering the carbohydrates more accessible in the hetero matrix. Removing lignin increases the reactivity of the remaining polysaccharides [26] since biodegradability of many lignocellulosic compounds are associated with the fractions of hemicellulose, cellulose, and lignin [33]. Mechanical pre-treatments increase the specific surface area of the feedstock available for the microbes as well as resulting in intracellular compound release $[34,35]$. Furthermore, it provides a greater digestate dewaterability and no odour generation [36]. In addition to chemical and mechanical pre-treatments, thermal pre-treatments are widely studied pre-treatment methods and have been successfully applied as a conditioning process for the sludge at industrial scale due to its ability to improve the pathogen elimination and dewaterability of the wastes $[4,36]$. The main effect of thermal pre-treatment of feedstock is dispersion of cell membranes, therefore resulting in solubilisation of organic compounds. A wide range of thermal pre-treatments may be performed, from 60 to $270{ }^{\circ} \mathrm{C}[37,38]$, however, the most commonly accepted optimum range is $160-180^{\circ} \mathrm{C}$. Therefore, thermal pre-treatments are considered as energy intensive methods [39]. Formation of inhibitory compounds are seen though Maillard reactions between amino acids and carbohydrates resulting in the generation of complex substrates and melanoidins (high-molecular-weight heterogeneous polymers), which are difficult to degrade [32,38-42] during the thermal pre-treatments. Therefore, chemical and mechanical pre-treatments are the most commonly applied techniques treating lignocellulosic biomass due to their implementation, simplicity and lower energy requirements with regard to thermal pre-treatments.

In this study, the organic, inorganic and lignocellulosic characterization of pot ale from a whisky distillery and a novel hybrid chemical/mechanical pre-treatment method (combined alkaline and beating) for anaerobic digestion is introduced to the literature for the first time. In addition, the impact of alkaline pre-treatment is evaluated by observing the changes in the lignocellulosic fraction of pot ale 
and spent grain prior to and after pre-treatment. To the best of the authors' knowledge, these topics were not addressed before. A lab scale batch reactor was employed to carry out the reactions and concentration of the common volatile fatty acids (VFA) (acetic acid, propionic acid, isobutyric acid, butyric acid, isovaleric acid and valeric acid [43-45]) which are related to inhibition were measured before and after AD. Mathematical models were developed to elucidate the interactions of operating parameters for $\mathrm{AD}$ of pot ale alone and mixed with spent grain.

\section{Materials and Methods}

Pot ale and spent grain were supplied by a small-scale whiskey distillery in Dublin. Seed sludge was used as inoculum and it was collected from an anaerobic digestion plant processing mixed food waste operating within the mesophilic range based in Ireland.

\subsection{Sample Characterisation}

Pot ale samples were initially characterised in terms of solid content; total solids (TS), volatile solids (VS), and moisture content (MC) in accordance with [46]. The concentrations of phosphorous (Molybdovanate Hach Method 8114) and nitrogen in forms of nitrate (Cadmium Reduction Hach Method 8039), nitrite (Ferrous Sulphate Hach Method 8153) were determined by using Hach DR 2000 Spectrometer and ammonia (Salicylate Test N Tube Hach Method 10031) was measured by using Hach DR 900 Spectrometer as part of sample characterisation. The concentrations of copper, iron, magnesium, manganese, and zinc of the pot ale were determined using ICP_OES (Agilent 5100).

Hemicellulose, cellulose, and lignin contents of pot ale and spent grain were measured according to the detergent method developed by $[47,48]$ prior to and after the implementation of each pre-treatment for evaluation of amendment of lignocellulosic structure with regard to the applied pre-treatment to enhance $\mathrm{AD}$ yield.

Chemical oxygen demand (COD), biological oxygen demand (BOD), and sulphate concentration were measured prior to and after AD in order to evaluate the efficiency of organic matter removals and bacterial competition between methanogenic and sulphate reducing bacteria as well as for characterising pot ale as received. COD and sulphate concentration were measured according to Hach Method 8000 by using standard Hach high range plus vials $(0-15,000$ ppm) and USEPA Sulfa-Ver 4 Hach Method 8051 provided by Hach Lange Company respectively, and DR 2000 spectrometer was used for the measurement. BOD was measured using the Lovibon BD600 unit provided by Lennox. To prevent the risk of sludge masking on organic content removals, the supernatant of all samples was analysed in the form of a mix of sludge after centrifuging at 10,000 rpm for $30 \mathrm{~min}$ using a Sorvall RC 5B Plus centrifuge $[49,50]$. Similarly, concentrations of acetic acid, propionic acid, isobutyric acid, butyric acid, isovaleric acid and valeric acid were determined using gas chromatography (Agilent 7890) with an Agilent CP 7686 column, in order to calculate total short chain volatile fatty acids in substrate (pot ale) for sample characterisation as well as substrate and inoculum mixture prior to and after AD to assess potential VFA inhibition [51].

\subsection{Hollander Beater Specifications}

The Hollander Beater specifications were explained in detail by [52], having been shown to be an excellent tool for pre-treatment of solid wastes prior to anaerobic digestion. The beater can perform a cutting action as a result of rotation of the bladed drum and a high-pressure homogenisation action caused by an inclined plate located at the exit of the drum concurrently. Therefore, the Hollander beater combines the effects of particle size reduction and substrate homogenization which is essential for pre-treatment of high solid content biomass.

\subsection{Bioreactor Set-Up}

A lab scale batch system was used as anaerobic digester. The bioreactors consist of 2 main parts which are $500 \mathrm{~mL}$ conical flasks with an active working volume of $400 \mathrm{~mL}$, and the $5 \mathrm{~L}$ capacity 
biogas compatible sampling bag (Figure 1). The connection in between those parts is provided by plastic tubing, quick release tubing connectors, and three-way valves. The system was flushed with nitrogen twice for 2 min to ensure anaerobic conditions [53,54]. Water baths were employed to keep the reactors at a constant mesophilic reaction temperature. A biogas analyser, BIOGASS 5000, was used for the qualitative and quantitative analysis of the generated biogas. The biogas quality and quantity was measured based upon DIN 2006 standard 38 414-8 explained by [54] which is commonly used for biomethane potential tests (BMP) at lab and pilot scales. The residence time was 21 days due to significant decrease in biogas generation (less than $1 \%$ of the previous measurement) after that time period.

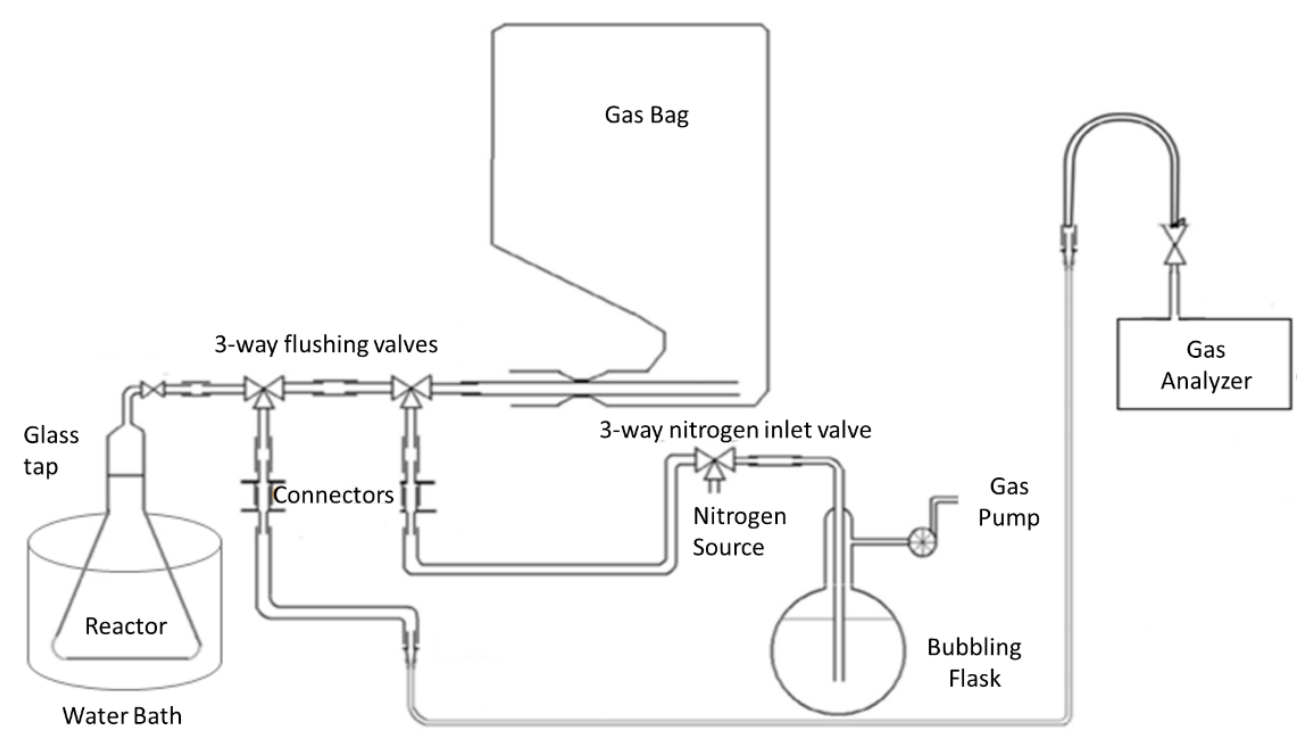

Figure 1. Bioreactor set up.

\subsection{Experimental Methodologies}

Pot ale was chosen as the main substrate of AD. Biodegradability of pot ale was assessed and the effects of increased solids content within the reactors was tested by anaerobic co-digestion (AcoD) of pot ale and spent grain.

\subsubsection{Assessment of the Pre-Treatments}

Initial screening experiments were performed to assess the impact of alkaline and beating pre-treatment on AD of pot ale. Alkaline pre-treatment was performed in accordance with the literature [31,32] in $400 \mathrm{~mL}$ batches by dropwise addition of $1 \mathrm{M} \mathrm{NaOH}$ into the pot ale sample until pH 10 was obtained. Once pH 10 [29] was achieved the sample was kept stirred for 6 min at $600 \mathrm{rpm}$. For alkaline pre-treatment of spent grain, the total volume of $400 \mathrm{~mL}$ was kept constant and spent grain was treated with required amount of $\mathrm{pH} 10$ adjusted DI water by dropwise addition of $1 \mathrm{M} \mathrm{NaOH}$ to obtain a spent grain:DI water ratio of $1: 5$ by weight. For beating pre-treatment, the beater was fed with $25 \mathrm{~L}$ of alkali pot ale sample to have a full circulation in the beating tub. Beating pre-treatment was performed on pot ale prior to, after and without $\mathrm{pH} 101 \mathrm{M} \mathrm{NaOH}$ treatment for 0, 5, and $7.5 \mathrm{~min}$. All samples were seeded with $50 \%$ of sludge (by volume, on wet basis).

The modifications in the lignocellulosic character of pot ale and spent grains were measured prior to and after the application of the alkali pre-treatment. Samples were subjected to sequential steps of hydrolysis and extraction using different reactants (neutral detergent, acid detergent, and $72 \%$ $\mathrm{H}_{2} \mathrm{SO}_{4}$ solution), in order to assess the lignocellulosic fractions with respect to their sensitivity to acid hydrolysis [48]. However, influences of beating pre-treatment on the lignocellulosic structure could 
not be assessed because of grinding requirement (particle size between $0.5 \mathrm{~mm}$ and $1 \mathrm{~mm}$ ) of the Van Soest method [48].

\subsubsection{Evaluating the Effects of Increased Solid Content on Anaerobic Digestion Performance}

In order to evaluate the impacts of increased solid content on anaerobic digestion, spent grain and pot ale were seeded with $50 \%$ sludge (on wet basis) of the total working volume of $400 \mathrm{~mL}$ with different mixing ratios $\left(1: 1,1: 3\right.$, and 1:5 by wet weight); the experiments were performed at $35^{\circ} \mathrm{C}$. Impacts of alkaline pre-treatment stands alone and in combination with 7.5 and $15 \mathrm{~min}$ beating pre-treatment on biogas generation and quality were investigated while a non-treated sample was kept as the control for each mixing ratio. The pre-treatments were performed according to Section 2.4.1.

\subsubsection{DOE for AD of Pot Ale and Pot Ale and Spent Grain Mix (5:1 by Wet Weight)}

A Box Behnken design of experiments (for process optimisation using Response Surface Modelling (RSM) involving three numerical factors, A: beating time, B: temperature, C: sludge $\%$, was adopted as the RSM.

Pot ale samples were treated with $1 \mathrm{M} \mathrm{NaOH}$ first, then beaten for $0,7.5$, and $15 \mathrm{~min}$. The required ratio of sample and sludge $(10,30$, and $50 \%$ sludge) for $400 \mathrm{~mL}$ of total volume were place into $500 \mathrm{~mL}$ conical flasks and $\mathrm{AD}$ experiments were performed at three different temperatures under mesophilic conditions $\left(32,35\right.$, and $\left.38^{\circ} \mathrm{C}\right)$, as specified in Table 1 . All experiments were performed in triplicate as indicated for each parameter (beating time, sludge percentages, and temperature). The same design parameters were followed for AcoD of pot ale and spent grain mix.

Table 1. Summary of the design factors, factor levels and the responses.

\begin{tabular}{|c|c|c|}
\hline $\begin{array}{c}\text { Parameters Under Investigation } \\
\text { (Design Factors) }\end{array}$ & Levels & Responses \\
\hline \multirow{4}{*}{ Beating time (min) } & 1. & \\
\hline & 7.5 & \\
\hline & 15 & 1. Biogas Yield (ml/g VS) \\
\hline & & 2. $\mathrm{CH}_{4} \%$ \\
\hline \multirow{3}{*}{ Digestion temperature $\left({ }^{\circ} \mathrm{C}\right)$} & 32 & 3. $\mathrm{CO}_{2} \%$ \\
\hline & 35 & \\
\hline & 38 & \\
\hline \multirow{3}{*}{ Sludge seeding ratio (\%) } & 10 & \\
\hline & 30 & \\
\hline & 50 & \\
\hline
\end{tabular}

Experimental data was examined by stepwise regression and the best fit was achieved by a second order polynomial Equation (1) in order to identify the relevant mathematical model terms. Sequential F-test, lack of fit test, as well as adequacy measures were then implemented in obtaining the best models. The same statistical software was used to generate response plots [52,55-57]

$$
\mathrm{Y}=\mathrm{b}_{0}+\sum \mathrm{b}_{\mathrm{i}} \mathrm{X}_{\mathrm{i}}+\sum \mathrm{b}_{\mathrm{ii}} \mathrm{X}^{2}{ }_{\mathrm{ii}}+\sum \mathrm{b}_{\mathrm{ij}} \mathrm{X}_{\mathrm{i}} \mathrm{X}_{\mathrm{j}}
$$

Both probability $>\mathrm{F}$ (also called as $p$-value) of the model and the value of each term in the model was computed by analysis of variance (ANOVA). Only if a Prob. $>F$ of the model and of each term in the model was smaller than the level of significance (in this study $\alpha=0.05$ ), in the confidence interval $(1-\alpha)$, the model is considered to be adequate. Developed models were then challenged and validated by independent experiments. The reduced model passed all the required statistical tests to be used 
to predict system responses and optimisation [56]. Paired $t$-tests were conducted on the predicted and the independent experiment results for statistical analysis. Both designs were then optimised by using a combination of numerical and graphical optimisation by employing the desirability function explained in detail by [58] offered by DOE software.

\section{Results}

\subsection{Results of Initial Screening}

\subsubsection{Sample Characterisation and Assessment of Pre-Treatments}

Characteristics of pot ale sample as received in terms of in terms of TS, VS, moisture content, COD, $\mathrm{BOD}$, sulphate, phosphorous, nitrogen-nitrate, nitrogen-nitrite, nitrogen-ammonium, hemicellulose, cellulose, lignin, VFAs, and dissolved copper are given in Table 2.

Table 2. Characteristics of pot ale as received.

\begin{tabular}{|c|c|}
\hline Compound & Value \\
\hline TS (g/g sample) & $0.089 \pm 0.0004$ \\
\hline VS (g/g sample) & $0.077 \pm 0.008$ \\
\hline Moisture\% & $91.13 \pm 0.042$ \\
\hline $\mathrm{COD}(\mathrm{mg} / \mathrm{L})$ & $38,867 \pm 115$ \\
\hline $\mathrm{BOD}(\mathrm{mg} / \mathrm{L})$ & $30,965 \pm 666$ \\
\hline $\mathrm{SO}_{4}{ }^{2-}(\mathrm{mg} / \mathrm{L})$ & $190 \pm 31$ \\
\hline * VFAs (mM) & 134.89 \\
\hline Hemicellulose (\%) & $11.5 \pm 0.3$ \\
\hline Cellulose $(\%)$ & $10.6 \pm 1.8$ \\
\hline Lignin (\%) & $26.9 \pm 1.6$ \\
\hline $\mathrm{P}_{-} \mathrm{PO}_{4}{ }^{3-}(\mathrm{mg} / \mathrm{L})$ & $778 \pm 7$ \\
\hline $\mathrm{N}^{-\mathrm{NO}_{3}}{ }^{-}(\mathrm{mg} / \mathrm{L})$ & $111 \pm 20$ \\
\hline $\mathrm{N}-\mathrm{NH}_{3}(\mathrm{mg} / \mathrm{L})$ & $45 \pm 7$ \\
\hline $\mathrm{N}-\mathrm{NO}_{2}{ }^{-}(\mathrm{mg} / \mathrm{L})$ & $33 \pm 4$ \\
\hline $\mathrm{Cu}(\mathrm{mg} / \mathrm{L})$ & $53.04 \pm 3.21$ \\
\hline $\mathrm{Fe}(\mathrm{mg} / \mathrm{L})$ & $2.55 \pm 0.21$ \\
\hline $\mathrm{Mg}(\mathrm{mg} / \mathrm{L})$ & $107.28 \pm 0.44$ \\
\hline $\mathrm{Mn}(\mathrm{mg} / \mathrm{L})$ & $0.30 \pm 0.01$ \\
\hline $\mathrm{Zn}(\mathrm{mg} / \mathrm{L})$ & $0.49 \pm 0.01$ \\
\hline
\end{tabular}

Average of triplicate runs except for * single run.

The effects of alkaline pre-treatment on lignocellulosic structure was assessed for pot ale and spent grain. After implementation of alkaline pre-treatment on both pot ale and spent grain, significant increases and decreases were seen in the hemicellulose and lignin contents respectively while cellulose remained static (Figure 2a,b). One-way ANOVA tests indicated that $1 \mathrm{M} \mathrm{NaOH}$ pre-treatment led to a significant increase (5\%) in hemicellulose fraction and a significant decrease $(9 \%)$ in lignin fraction of pot ale with the $p$-values of 0.032 and 0.0254 respectively. In case of spent grain, alkaline pre-treatment achieved a significant increase in hemicellulose fraction (16\%) and a significant decrease $(10 \%)$ in lignin fraction with the $p$-values of 0.00032 and 0.000032 , respectively.

The biogas results of the initial screening experiments for combined $1 \mathrm{M} \mathrm{NaOH}$ and beating pre-treatment for 5, 7.5, and $15 \mathrm{~min}$ are given in Table 3. 


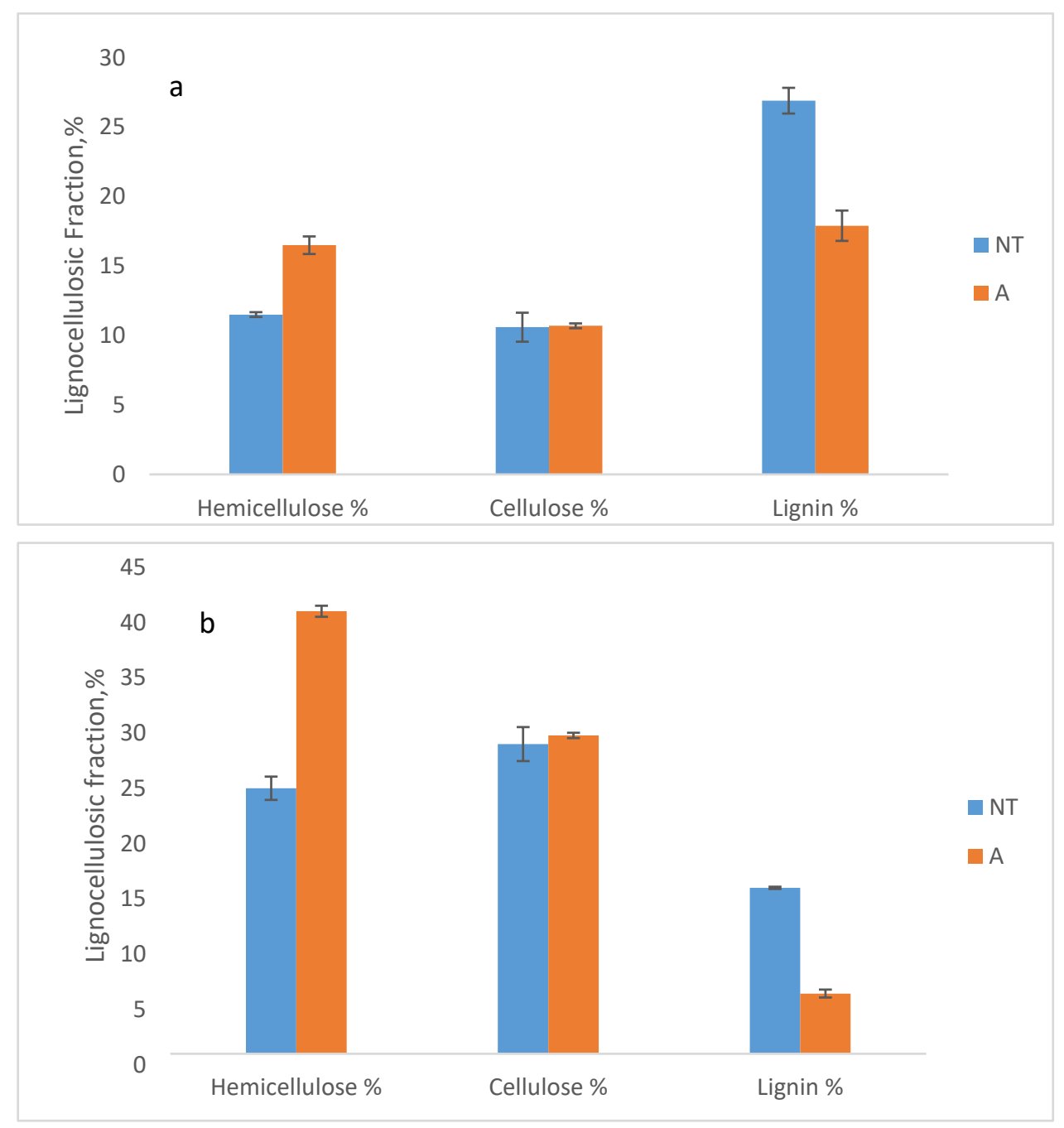

Figure 2. Lignocellulosic structure of pot ale (a) and, spent grain (b) before and after alkali pre-treatment. NT: non-treated, A: alkaline pre-treated average of triplicate runs.

Table 3. Biogas yields following preliminary experiments with nontreated and pre-treated pot ale.

\begin{tabular}{cccccc}
\hline Sample Names & $\begin{array}{c}\text { TS } \\
\text { (g/g Sample) }\end{array}$ & $\begin{array}{c}\text { VS } \\
\text { (g/g Sample) }\end{array}$ & $\begin{array}{c}{ }^{*} \text { Biogas } \\
\text { (mL/g VS) }\end{array}$ & CH $_{\mathbf{4}} \%$ & CO $_{\mathbf{2}} \%$ \\
\hline Nontreated sample (control) & 0.089 & 0.077 & $205 \pm 21.4$ & 19.3 & 65.1 \\
Alkaline (A0B) & 0.088 & 0.070 & $523 \pm 10.4$ & 48.1 & 35.8 \\
5 min beaten + alkaline (B5A) & 0.086 & 0.069 & $476 \pm 6.2$ & 37.1 & 47.3 \\
Alkaline + 5 min beaten (AB5) & 0.095 & 0.077 & $541 \pm 19.4$ & 49.5 & 45.3 \\
7.5 min beaten + alkaline (B7.5A) & 0.087 & 0.070 & $555 \pm 5.3$ & 43.0 & 52.3 \\
Alkaline + 7.5 min beaten (AB7.5) & 0.090 & 0.070 & $629 \pm 8.5$ & 51.3 & 42.6 \\
\hline
\end{tabular}

* Average of duplicate runs.

The highest cumulative biogas production was achieved with alkaline pre-treatment following by beating for $7.5 \mathrm{~min}$ (AB7.5) as $629 \pm 8.5 \mathrm{~mL} / \mathrm{g}$ vs. where the control could only reach $205 \pm 21.4 \mathrm{~mL} / \mathrm{g}$ vs. indicating that hybrid pre-treatment resulted in 3-fold enhancement ( $p: 0.0029)$ in biogas yield. Similarly, the highest $\mathrm{CH}_{4}$ content was seen as $51.3 \%$ in AB7.5. Moreover, a $p$-value of $0.0032(<0.05)$ was found by application of a one-way ANOVA, indicating that the order in which the pre-treatments were performed had a significant effect on total biogas generation. As such, alkaline pre-treatment followed by beating pre-treatment was selected as the baseline hybrid pre-treatment for further experiments. 


\subsubsection{AcoD of Pot Ale and Spent Grain Mixture}

The total solids, volatile solids, and moisture content of spent grain and pot ale mixed in ratios of 1:1, 1:3, and 1:5 by wet weight are given in Table 4 . The cumulative biogas quantity and quality is given in Figure 3 and Table 5, respectively. The unknown content within the produced biogas was referred as BAL.

Table 4. TS, VS, and Moisture $\%$ of the non- and pre-treated pot ale and spent grain mix.

\begin{tabular}{cccc}
\hline Sample Name & TS (g/g Sample) & VS (g/g Sample) & Moisture (\%) \\
\hline 1:1 NT & $0.181 \pm 0.018$ & $0.161 \pm 0.004$ & $81.86 \pm 1.8$ \\
1:1 A 0B & $0.183 \pm 0.004$ & $0.163 \pm 0.007$ & $81.70 \pm 0.4$ \\
1:1 A 7.5B & $0.195 \pm 0.190$ & $0.178 \pm 0.001$ & $80.53 \pm 1.9$ \\
1:1 A 15B & $0.197 \pm 0.012$ & $0.174 \pm 0.002$ & $80.34 \pm 1.2$ \\
1:3 NT & $0.143 \pm 0.003$ & $0.134 \pm 0.011$ & $85.70 \pm 0.3$ \\
1:3 A 0B & $0.147 \pm 0.010$ & $0.141 \pm 0.002$ & $85.35 \pm 1.0$ \\
1:3 A 7.5B & $0.153 \pm 0.002$ & $0.145 \pm 0.005$ & $84.67 \pm 0.2$ \\
1:3 A 15B & $0.137 \pm 0.015$ & $0.115 \pm 0.008$ & $86.26 \pm 1.5$ \\
1:5 NT & $0.112 \pm 0.007$ & $0.114 \pm 0.009$ & $88.77 \pm 0.7$ \\
1:5 A 0B & $0.121 \pm 0.004$ & $0.100 \pm 0.007$ & $87.85 \pm 0.4$ \\
1:5 A 7.5B & $0.115 \pm 0.007$ & $0.089 \pm 0.008$ & $88.55 \pm 0.7$ \\
1:5 A 15B & $0.117 \pm 0.014$ & $0.110 \pm 0.005$ & $88.27 \pm 1.4$
\end{tabular}

All results are average of triplicate runs.

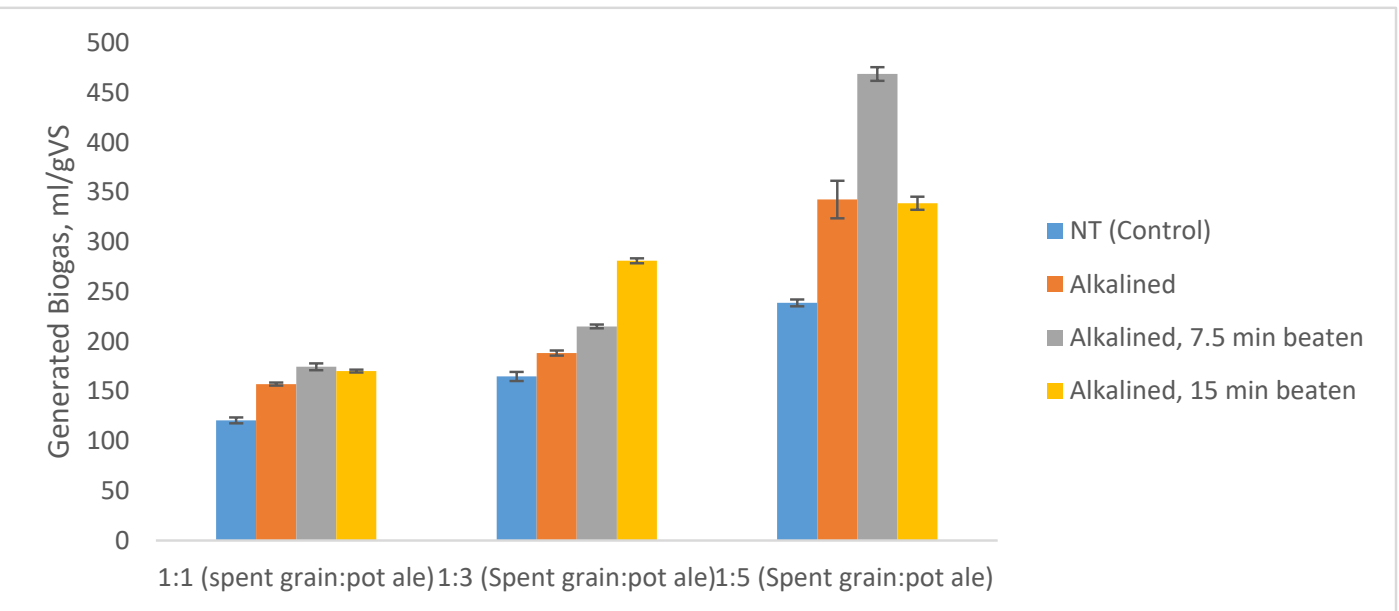

Figure 3. Biogas yields of spent grain and pot ale mixtures after alkaline and beating pre-treatments. Average of triplicate runs.

Table 5. Components of generated biogas by anaerobic digestion of spent grain and pot ale mixtures.

\begin{tabular}{cccccc}
\hline Sample & $* \mathbf{C H}_{\mathbf{4}} \mathbf{*}$ & ${ }^{*} \mathbf{C O}_{\mathbf{2}} \%$ & ${ }^{*} \mathbf{B A L} \%$ & $\mathbf{H}_{\mathbf{2}} \mathbf{S}(\mathbf{p p m})$ & Final $\mathbf{p H}$ \\
\hline 1:1 Control & $42.3 \pm 9$ & $44.0 \pm 8$ & 9.6 & 1572 & 5.33 \\
1:1 A0B & $50.0 \pm 3$ & $39.1 \pm 2$ & 9.3 & 1273 & 5.47 \\
1:1 A7.5B & $50.5 \pm 5$ & $34.4 \pm 7$ & 13.3 & 632 & 5.57 \\
1:1 A15B & $45.3 \pm 2$ & $40.1 \pm 2$ & 10.6 & 896 & 5.48 \\
1:3 Control & $50.5 \pm 3$ & $39.9 \pm 3$ & 8.4 & 1628 & 5.37 \\
1:3 A0B & $52.4 \pm 6$ & $42.9 \pm 4$ & 9.3 & 1354 & 5.54 \\
1:3 A7.5B & $48.5 \pm 3$ & $41.2 \pm 3$ & 10.6 & 1692 & 5.34 \\
1:3 A15B & $48.4 \pm 3$ & $40.7 \pm 1$ & 9.0 & 1120 & 5.78 \\
1:5 Control & $49.1 \pm 2$ & $34.0 \pm 1$ & 7.9 & 800 & 5.44 \\
1:5 A0B & $51.4 \pm 3$ & $34.5 \pm 4$ & 12.1 & 834 & 5.67 \\
1:5 A7.5B & $53.3 \pm 1$ & $35.2 \pm 6$ & 17.3 & 913 & 5.78 \\
1:5 A15B & $50.9 \pm 3$ & $37.9 \pm 1$ & 9.4 & 757 & 5.75 \\
\hline
\end{tabular}

* Average of triplicate runs. 
The highest biogas yields were achieved with the mixing ratio of 1:5 regardless of the condition of pre-treatments. Among the sample group with 1:5 spent grain pot ale mixing $1 \mathrm{M} \mathrm{NaOH}$ pre-treatment followed by $7.5 \mathrm{~min}$ beating had the highest yield of $469 \pm 7 \mathrm{~mL} / \mathrm{g}$ vs. with a $\mathrm{CH}_{4}$ content of $53.3 \pm 1 \%$. It also found to be significantly higher than both $1 \mathrm{M} \mathrm{NaOH}$ pre-treatment alone and followed by 15 min beating with the $p$-values of 0.0033 and 0.00016 respectively.

On the other hand, no significant difference was found in the biogas quality regarding the different pre-treatment conditions or mixing ratios. The $\mathrm{pH}$ drops from 7 to around 5.5 was observed with all samples. For modelling of AcoD of spent grain and pot ale, a mixing ratio of 1:5 was chosen based on preliminary experiment results.

\subsection{Design of Experiments and Organic Removals}

The Box-Behnken design matrix for AD of Pot ale is given in Table 6 with experiment results. A variety of methane content was seen in the generated biogas. The maximum biogas quality and quantity were achieved with the std. no. 12 as $550 \pm 6 \mathrm{~mL} / \mathrm{g}$ vs. and $54.3 \% \mathrm{CH}_{4}$ in respectively. Although all reactions were started at the neutral $\mathrm{pH}$, mainly low final $\mathrm{pH}$ values were seen in all samples with a slight difference (higher) in the ones seeded $50 \%$ sludge, however it was still lower than optimum $\mathrm{pH}$ range for methanogens (std. no. 7, 8, 11, and 12). The same particular samples also had significantly higher $\mathrm{CH}_{4}$ percentages than the rest.

Table 6. Design matrix for AD of pot ale.

\begin{tabular}{|c|c|c|c|c|c|c|c|c|}
\hline Std. & Run & $\begin{array}{c}\text { Factor } 1 \\
\text { A:BT } \\
\text { min }\end{array}$ & $\begin{array}{c}\text { Factor } 2 \\
\text { B:Temp } \\
{ }^{\circ} \mathrm{C}\end{array}$ & $\begin{array}{c}\text { Factor } 3 \\
\text { C:Sludge } \\
\%\end{array}$ & $\begin{array}{c}\text { Response } 1 \\
\text { * Biogas } \\
\text { mL/g VS }\end{array}$ & $\begin{array}{c}\text { Response } 2 \\
\mathrm{CH}_{4} \\
\%\end{array}$ & $\begin{array}{c}\text { Response } 3 \\
\mathrm{CO}_{2} \\
\%\end{array}$ & $\begin{array}{c}\text { Final } \\
\text { pH }\end{array}$ \\
\hline 1 & 16 & 0 & 32 & 30 & $145 \pm 9$ & 3.4 & 42.1 & 5.24 \\
\hline 2 & 5 & 15 & 32 & 30 & $177 \pm 11$ & 5.4 & 39 & 5.61 \\
\hline 3 & 8 & 0 & 38 & 30 & $173 \pm 7$ & 3.8 & 33.8 & 5.47 \\
\hline 4 & 11 & 15 & 38 & 30 & $214 \pm 6$ & 6.2 & 43.9 & 5.34 \\
\hline 5 & 12 & 0 & 35 & 10 & $109 \pm 5$ & 1.5 & 16.7 & 5.41 \\
\hline 6 & 9 & 15 & 35 & 10 & $134 \pm 7$ & 1.7 & 15.9 & 5.17 \\
\hline 7 & 10 & 0 & 35 & 50 & $400 \pm 19$ & 46.8 & 22.4 & 6.12 \\
\hline 8 & 4 & 15 & 35 & 50 & $510 \pm 17$ & 48.7 & 24.4 & 6.51 \\
\hline 9 & 6 & 7.5 & 32 & 10 & $141 \pm 3$ & 1 & 35.4 & 5.42 \\
\hline 10 & 2 & 7.5 & 38 & 10 & $124 \pm 9$ & 1.4 & 13.2 & 5.38 \\
\hline 11 & 1 & 7.5 & 32 & 50 & $532 \pm 12$ & 43.6 & 26.7 & 6.45 \\
\hline 12 & 13 & 7.5 & 38 & 50 & $550 \pm 6$ & 54.3 & 29.4 & 6.24 \\
\hline 13 & 15 & 7.5 & 35 & 30 & $180 \pm 20$ & 3.1 & 41.2 & 5.71 \\
\hline 14 & 14 & 7.5 & 35 & 30 & $223 \pm 12$ & 4.6 & 38.4 & 5.64 \\
\hline 15 & 7 & 7.5 & 35 & 30 & $190 \pm 9$ & 2.5 & 37.5 & 5.24 \\
\hline 16 & 17 & 7.5 & 35 & 30 & $211 \pm 7$ & 3.5 & 48.4 & 5.21 \\
\hline 17 & 3 & 7.5 & 35 & 30 & $217 \pm 8$ & 2.9 & 41.9 & 5.43 \\
\hline
\end{tabular}

* Average of duplicate runs.

The percentage removals of the organic compounds are given in Table 7. Mainly higher COD and BOD removals were achieved with the samples seeded with $50 \%$ sludge (std. no. $7,8,11$, and 12 in Table 7) suggesting the higher sludge amount delayed the $\mathrm{pH}$ drops thus methanogens could survive longer to transform the organic matter into $\mathrm{CH}_{4}$. The $\mathrm{pH}$ drops were explained with VFA (acetic acid, propionic acid, isobutyric acid, butyric acid, isovaleric acid, and valeric acid) accumulation in the reactors. The total VFAs concentrations before and after AD are given in Figure 4.

In contrast, the highest $\mathrm{SO}_{4}$ decompositions were seen the samples which contain 10 and $30 \%$ sludge while $\mathrm{SO}_{4}$ removal of $50 \%$ sludge contain samples was almost one-third of the values obtained with $30 \%$ sludge. Due to the bacterial competition, the sludge seeding ratio lower than $50 \%$ results in unsuitable environment for methanogenic bacteria growth, and it triggers the activity of the sulphate reducing bacteria. Digestion under these conditions results in low $\mathrm{CH}_{4}$ generation and high (>10,000 ppm) $\mathrm{H}_{2} \mathrm{~S}$ generation. 
Table 7. Percentages removal of organic after anaerobic digestion of pot ale.

\begin{tabular}{cccc}
\hline Exp No & COD & BOD & SO $_{4}$ \\
\hline $\mathrm{S} \%=10$ & & & \\
\hline 5 & $52 \pm 8$ & $50 \pm 9$ & $56 \pm 1$ \\
6 & $48 \pm 8$ & $43 \pm 4$ & $60 \pm 5$ \\
9 & $52 \pm 7$ & $47 \pm 9$ & $65 \pm 6$ \\
10 & $16 \pm 4$ & $22 \pm 1$ & $68 \pm 5$ \\
\hline $\mathrm{S} \%=30$ & & & \\
\hline 1 & $43 \pm 5$ & $44 \pm 6$ & $79 \pm 3$ \\
2 & $45 \pm 4$ & $49 \pm 4$ & $76 \pm 4$ \\
3 & $39 \pm 1$ & $37 \pm 3$ & $71 \pm 2$ \\
4 & $23 \pm 3$ & $41 \pm 5$ & \\
$13-17$ & $28 \pm 3$ & $60 \pm 5$ & $29 \pm 2$ \\
$\mathrm{~S} \%=50$ & & & $25 \pm 1$ \\
7 & $58 \pm 3$ & $55 \pm 6$ & $24 \pm 1$ \\
8 & $78 \pm 5$ & $61 \pm 4$ & $36 \pm 6$ \\
\hline 11 & $64 \pm 4$ & $49 \pm 2$ & \\
\hline
\end{tabular}

All results are average of triplicate runs.

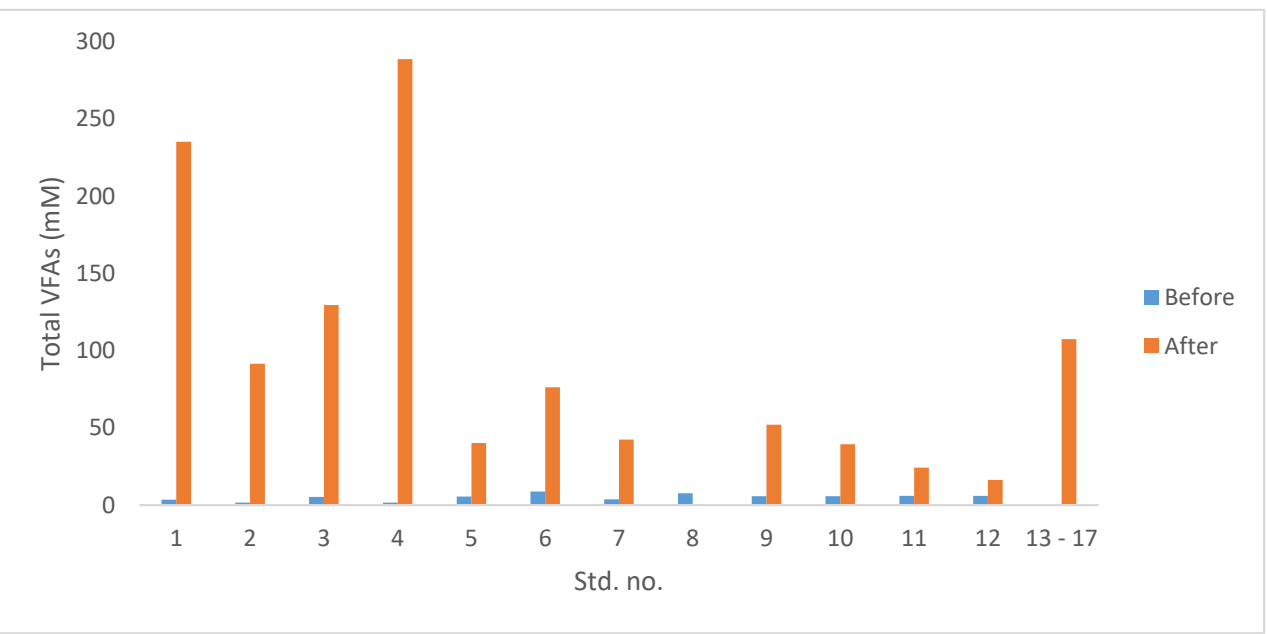

Figure 4. Total VFAs before and after AD of pot ale.

The VFA concentration after AD was found to be significantly higher for all samples. The std. no. $5,6,9,10,7,11$ and 12 (which were seeded with 30 and 50\% sludge) had lower total VFAs concentrations after $\mathrm{AD}$ in comparison to $10 \%$ sludge seeding. Moreover, $50 \%$ sludge containing samples (std. no. 7 , 8,11 , and 12) had significantly higher biogas yields with significantly higher methane contents (Table 6) indicating that they were not affected by VFA inhibition as much as the ones containing a lower sludge amount. The std. no. 12 in particular had the lowest total VFA value (16.12 mM) after AD and it had the highest biogas quality and the quantity (Table 6).

The same design was followed in order to evaluate the impact of process parameters on increased solid content after adding spent grain into pot ale (1:5, by wet weight). Design matrix with the corresponding responses is given in Table 8. A similar range of $\mathrm{CH}_{4}$ generation was seen with the previous design for $\mathrm{AD}$ of pot ale. The highest biogas quality and quantity were obtained with the std. no. 12 as $55 \pm 0.4 \% \mathrm{CH}_{4}$ in $360 \pm 10 \mathrm{~mL} / \mathrm{g}$ vs. biogas. Moreover, the final $\mathrm{pH}$ value for this particular sample was maintained within the neutral areas, whereas it dropped around the level of 5.5 for the other samples. 
Table 8. Design matrix for anaerobic co-digestion of pot ale and spent grain (5:1, by weight).

\begin{tabular}{|c|c|c|c|c|c|c|c|c|c|}
\hline Std. & Run & $\begin{array}{c}\text { Factor } 1 \\
\text { A:BT } \\
\text { min }\end{array}$ & $\begin{array}{c}\text { Factor } 2 \\
\text { B:Temp } \\
{ }^{\circ} \mathrm{C}\end{array}$ & $\begin{array}{c}\text { Factor } 3 \\
\text { C:Sludge } \\
\%\end{array}$ & $\begin{array}{c}\text { Response } 1 \\
\text { Biogas } \\
\text { mL/g VS }\end{array}$ & $\begin{array}{c}\text { Response } 2 \\
\mathrm{CH}_{4} \\
\%\end{array}$ & $\begin{array}{c}\text { Response } 3 \\
\mathrm{CO}_{2} \\
\%\end{array}$ & $\begin{array}{l}\mathrm{H}_{2} \mathrm{~S} \\
\text { ppm }\end{array}$ & $\begin{array}{c}\text { Final } \\
\mathrm{pH}\end{array}$ \\
\hline 1 & 16 & 0 & 32 & 30 & $49 \pm 2$ & $3.9 \pm 1.1$ & $56.8 \pm 1.8$ & $>>>$ & 5.5 \\
\hline 2 & 5 & 15 & 32 & 30 & $55 \pm 8$ & $10.0 \pm 0.8$ & $55.2 \pm 0.8$ & $>>$ & 5.4 \\
\hline 3 & 8 & 0 & 38 & 30 & $67 \pm 13$ & $8.5 \pm 0.7$ & $55.9 \pm 0.7$ & $>>>$ & 5.7 \\
\hline 4 & 11 & 15 & 38 & 30 & $84 \pm 11$ & $16.1 \pm 0.2$ & $56.2 \pm 1.5$ & $>>>$ & 5.7 \\
\hline 5 & 12 & 0 & 35 & 10 & $42 \pm 2$ & $2.2 \pm 0.3$ & $50.7 \pm 0.2$ & $>>>$ & 5.4 \\
\hline 6 & 9 & 15 & 35 & 10 & $50 \pm 5$ & $10.8 \pm 0.2$ & $55.1 \pm 0.8$ & $>>>$ & 5.6 \\
\hline 7 & 10 & 0 & 35 & 50 & $207 \pm 19$ & $28.0 \pm 2.1$ & $39.2 \pm 0.8$ & 1782 & 5.6 \\
\hline 8 & 4 & 15 & 35 & 50 & $279 \pm 11$ & $48.5 \pm 2.3$ & $35.0 \pm 1.7$ & 782 & 5.5 \\
\hline 9 & 6 & 7.5 & 32 & 10 & $57 \pm 3$ & $2.2 \pm 0.5$ & $52.8 \pm 1.6$ & $>>>$ & 5.4 \\
\hline 10 & 2 & 7.5 & 38 & 10 & $48 \pm 7$ & $4.9 \pm 1.4$ & $52.8 \pm 1.6$ & $>>>$ & 5.3 \\
\hline 11 & 1 & 7.5 & 32 & 50 & $258 \pm 8$ & $29.3 \pm 2.1$ & $48.2 \pm 8.3$ & 1472 & 5.6 \\
\hline 12 & 13 & 7.5 & 38 & 50 & $360 \pm 10$ & $55.0 \pm 0.4$ & $36.0 \pm 0.3$ & 1375 & 7.1 \\
\hline 13 & 15 & 7.5 & 35 & 30 & $63 \pm 11$ & $14.0 \pm 1.4$ & $51.8 \pm 2.7$ & $>>>$ & 5.5 \\
\hline 14 & 14 & 7.5 & 35 & 30 & $69 \pm 9$ & $13.0 \pm 0.9$ & $5.70 \pm 1.8$ & $>>>$ & 5.5 \\
\hline 15 & 7 & 7.5 & 35 & 30 & $76 \pm 8$ & $13.8 \pm 0.7$ & $57.5 \pm 2.1$ & $>>>$ & 5.4 \\
\hline 16 & 17 & 7.5 & 35 & 30 & $46 \pm 4$ & $15.0 \pm 0.5$ & $59.1 \pm 3.4$ & $>>$ & 5.3 \\
\hline 17 & 3 & 7.5 & 35 & 30 & $61 \pm 7$ & $14.5 \pm 0.7$ & $53.6 \pm 3.7$ & $>>>$ & 5.3 \\
\hline
\end{tabular}

All results are average of triplicate runs.

The percentage removal of $\mathrm{COD}, \mathrm{BOD}$, and $\mathrm{SO}_{4}$ due to bacterial activity is given in Table 9 . The experiments performed with $10 \%$ and $30 \%$ sludge resulted in low COD and BOD removal percentage levels regardless of the application of the pre-treatments, correspondingly low levels of biogas yields were seen in those samples. Pre-treatments, however, had a significant impact on biogas quality for the same samples i.e., the std. no. 1,2 and 5,6 in (Table 8), $\mathrm{CH}_{4 \%}$ increased 2- and 5-fold over due to the effect of $15 \mathrm{~min}$ beating pre-treatment, respectively. It can be explained by, in early stage of anaerobic digestion, the extended active surface area on solid material in the reactors stimulated microbial activity which resulted in higher $\mathrm{CH}_{4}$ generation. However, the availability of large amounts of fresh feedstock caused imbalanced reaction rates, sequentially sharp $\mathrm{pH}$ drops inhibitory level in particular for the acetoclastic methanogens. The percentage of sulphate removal was found to be significantly higher for the samples seeded with 10 and 30\% sludge, which also indicating higher activity of sulphate reducing bacteria with regard to methanogenic bacteria. Moreover, excessive $\mathrm{H}_{2} \mathrm{~S}$ production levels (reaching beyond the sensor range $>10000 \mathrm{ppm}$ ) in the samples contain 10 and 30\% sludge supported the same statement.

Table 9. Percentage removal of organic compounds after AD of pot ale and spent grain (5:1, by weight).

\begin{tabular}{cccc}
\hline Exp. No. & COD & BOD & SO $_{4}$ \\
\hline $\mathrm{S} \%=10$ & & & \\
\hline 5 & $12 \pm 2$ & $14 \pm 1$ & $95 \pm 2$ \\
6 & $23 \pm 3$ & $17 \pm 1$ & $74 \pm 4$ \\
9 & $11 \pm 1$ & $22 \pm 3$ & $87 \pm 1$ \\
10 & $9 \pm 1$ & $16 \pm 4$ & $69 \pm 7$ \\
\hline $\mathrm{S} \%=30$ & & \\
\hline 1 & $15 \pm 3$ & $25 \pm 2$ & $71 \pm 1$ \\
2 & $23 \pm 1$ & $14 \pm 1$ & $88 \pm 1$ \\
3 & $29 \pm 2$ & $29 \pm 6$ & $40 \pm 2$ \\
4 & $37 \pm 2$ & $32 \pm 4$ & $56 \pm 6$ \\
$13-17$ & $39 \pm 5$ & $33 \pm 7$ & $49 \pm 7$ \\
\hline $\mathrm{S} \%=50$ & & & \\
\hline 7 & $58 \pm 7$ & $40 \pm 3$ & $32 \pm 5$ \\
8 & $66 \pm 3$ & $46 \pm 2$ & $38 \pm 1$ \\
11 & $49 \pm 4$ & $48 \pm 5$ & $31 \pm 7$ \\
\hline 12 & $73 \pm 6$ & $63 \pm 7$ & \\
\hline
\end{tabular}

All results are average of triplicate runs. 
Significantly higher COD and BOD removals were achieved with the samples seeded with $50 \%$ sludge along with the lower $\mathrm{SO}_{4}$ removals (Table 9) in comparison to the lower sludge seeding ratios. In case of std. no. 7 and 8,15 min beating pre-treatment resulted in a significant rises in both biogas yield (from $207 \pm 19$ to $279 \pm 11 \mathrm{~mL} / \mathrm{g} \mathrm{VS}, p: 0.0093$ ) and quality $28.0 \pm 2.1$ to $48.5 \pm 2.3 \%$ (p: 0.0008) $\mathrm{CH}_{4}$ due to higher COD and BOD removals (Table 9). Moreover, the std. no. 8 had lower $\mathrm{H}_{2} \mathrm{~S}$ production ( $p$ : 0.0030 ) than 7 because of $9 \%$ less $\mathrm{SO}_{4}$ reduction (Table 9). Different digestion temperatures were seen to significantly influence biogas production and $\mathrm{CH}_{4}$ content (std. no. 11 and 12, Table 8). The digestion at $38^{\circ} \mathrm{C}$ increased the biogas generation yield from $258 \pm 8$ to $360 \pm 10 \mathrm{~mL} / \mathrm{g}$ vs. and the percentage, because of higher COD, BOD removals which are given in Table 9, the of $\mathrm{CH}_{4}$ from $29.3 \pm 2.1$ to $55.0 \pm 0.4$ with respect to the digestion at $35^{\circ} \mathrm{C}$. Furthermore, likewise in the std. no. 8 , a lower $\mathrm{H}_{2} \mathrm{~S}$ production was achieved with experiment no. 12 along with lower $\mathrm{SO}_{4}$ removal percentages (Table 9).

Results of the VFA analysis of pot ale spent grain mix before and after anaerobic digestion is given in Figure 5.

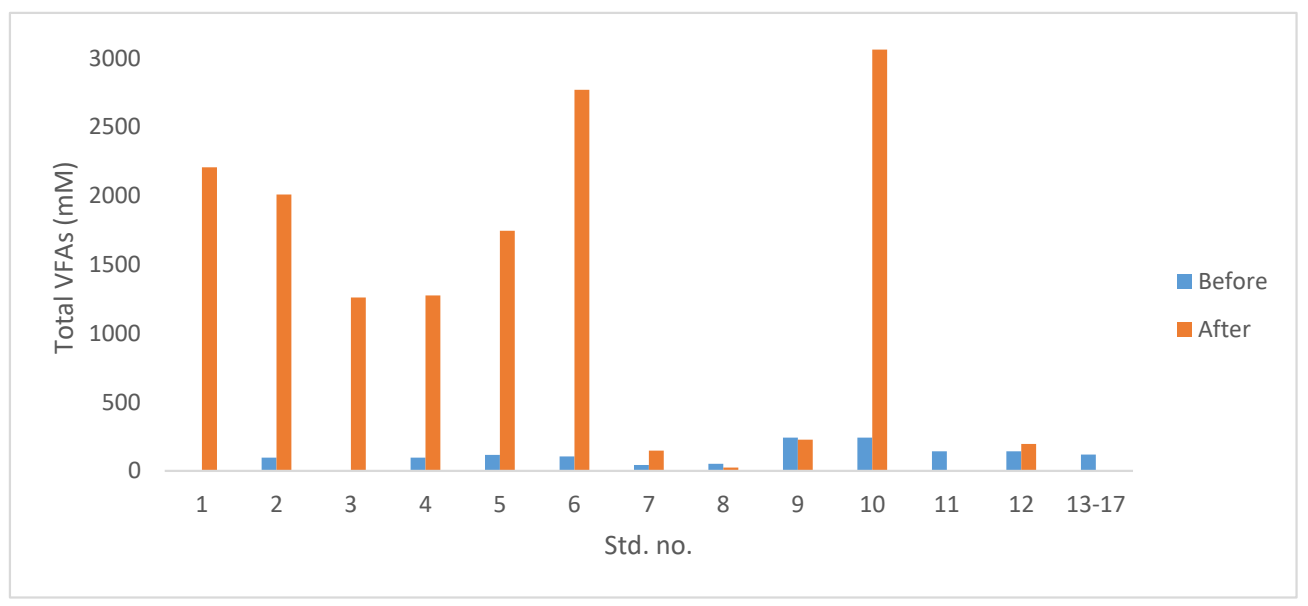

Figure 5. Total VFAs before and after AD of pot ale spent grain mix.

Although total VFA concentration of all samples after AD was so much higher than the initial corresponding values, samples which were seeded with 50\% sludge (sample nos. 7,11 in Figure 5) had the lowest final total VFAs values indicating that these particular samples were not affected by the VFA inhibition as much as the others [59]. Therefore, their biogas yields as well as methane percentage of the produced biogas is significantly higher than the samples seeded with lower sludge (Table 8). AD of pot ale spent grain mix have much higher final VFA concentration than pot ale alone even though the same design factors are applied for both feedstock types. This is attributed to higher impact of the lack of internal agitation within the system for $\mathrm{AD}$ of the mixed compounds, since it has higher solid content. In other words, microbes are physically blocked to reach spent grain which lead a competition for limited amount of pot ale as the feedstock.

\subsection{Mathematical Model Estimations}

The mathematical models were statistically analysed by ANOVA (using the coding format given in Table 10) and the summary of analysis is given in (Tables 11 and 12), (Tables 13 and 14) and (Tables 15 and 16) for biogas production, $\mathrm{CH}_{4}$ and $\mathrm{CO}_{2} \%$ for $\mathrm{AD}$ of pot ale, and spent grain and pot ale co-digestion respectively. For each experiment, developed models achieved an adequate fit with produced data within the identified significance threshold since the value of lack of fit was $<0.05$ for all models except for biogas generation by AD of spent grain and pot ale mix $<0.1$. In other words, estimated model on biogas production by AD of spent grain and pot ale had no significant lack of fit within $90 \%$ confidence interval, whereas the confidence interval is $95 \%$ for all other models. Furthermore, the values of $R^{2}$, adjusted $R^{2}$ (Adj. $R^{2}$ ) and predicted $R^{2}$ (Pred. $R^{2}$ ) were close to 1 for 
all models indicating a sufficient regression for the models, plus the difference between the adjusted $R^{2}$ (Adj. $R^{2}$ ) and predicted $R^{2}$ (Pred. $R^{2}$ ) was less than 0.2 . An adequate precision value greater than 4 indicates adequate model discrimination [60] achieved here in all cases. Mathematical models were built based on actual and coded factors allowing to plot different design factors with different units in the same graph to compare their individual effects on the response of interest.

Table 10. Coding format of the variables.

\begin{tabular}{lccc}
\hline \multicolumn{1}{c}{ Coded Factors } & & \\
\hline \multicolumn{1}{c}{ Variable } & $\mathbf{- 1}$ & $\mathbf{0}$ & $\mathbf{1}$ \\
\hline A: Beating Time & 0 & 7.5 & 15 \\
B: Temperature & 32 & 35 & 38 \\
C: Sludge $\%$ & 10 & 30 & 50 \\
\hline
\end{tabular}

Table 11. ANOVA table for biogas production by AD of pot ale quadratic model $\alpha=0.05$.

\begin{tabular}{|c|c|c|c|c|c|c|}
\hline Source & Sum of Squares & df & Mean Square & F Value & $\begin{array}{l}p \text {-Value } \\
\text { Prob > F }\end{array}$ & \\
\hline Model & $347,790.58$ & 4 & $86,947.64$ & 125.38 & $<0.0001$ & \multirow[t]{5}{*}{ significant } \\
\hline A-Beating Time, min & 5408 & 1 & 5408 & 7.80 & 0.0162 & \\
\hline C-Sludge, $\%$ & 275,282 & 1 & 275,282 & 396.95 & $<0.0001$ & \\
\hline $\mathrm{A}^{2}$ & 5829.66 & 1 & 5829.66 & 8.41 & 0.0133 & \\
\hline$C^{2}$ & $63,196.49$ & 1 & $63,196.49$ & 91.13 & $<0.0001$ & \\
\hline Residual & 8321.90 & 12 & 693.49 & \multirow{4}{*}{2.58} & & \multirow{4}{*}{$\begin{array}{c}\text { not } \\
\text { significant }\end{array}$} \\
\hline Lack of Fit & 6971.09 & 8 & 871.39 & & 0.1879 & \\
\hline Pure Error & 1350.8 & 4 & 337.7 & & & \\
\hline Cor Total & $356,112.47$ & 16 & & & & \\
\hline
\end{tabular}

Table 12. ANOVA table for biogas production by AD of spent grain and pot ale quadratic model $\alpha=0.01$.

\begin{tabular}{|c|c|c|c|c|c|c|}
\hline Source & Sum of Squares & df & Mean Square & F Value & $\begin{array}{l}p \text {-Value } \\
\text { Prob }>\text { F }\end{array}$ & \\
\hline Model & $1.50 \times 10^{5}$ & 4 & $37,568.12$ & 56.84 & $<0.0001$ & \multirow[t]{6}{*}{ significant } \\
\hline B-Temperature & 2455.95 & 1 & 2455.95 & 3.72 & 0.0779 & \\
\hline C-Sludge, $\%$ & $1.03 \times 10^{5}$ & 1 & $1.03 \times 10^{5}$ & 155.55 & $<0.0001$ & \\
\hline $\mathrm{BC}$ & 3039.32 & 1 & 3039.32 & 4.6 & 0.0532 & \\
\hline$C^{2}$ & $41,961.97$ & 1 & $41,961.97$ & 63.48 & $<0.0001$ & \\
\hline Residual & 7931.94 & 12 & 661 & \multirow{4}{*}{7.66} & \multirow{4}{*}{0.0331} & \\
\hline Lack of Fit & 7446.01 & 8 & 930.75 & & & \multirow[t]{3}{*}{$\begin{array}{c}\text { not } \\
\text { significant }\end{array}$} \\
\hline Pure Error & 485.93 & 4 & 121.48 & & & \\
\hline Cor Total & $1.58 \times 10^{5}$ & 16 & & & & \\
\hline
\end{tabular}

Table 13. ANOVA table for $\mathrm{CH}_{4} \%$ for AD of pot ale quadratic model $\alpha=0.05$.

\begin{tabular}{|c|c|c|c|c|c|c|}
\hline Source & Sum of Squares & df & Mean Square & F Value & $\begin{array}{l}p \text {-Value } \\
\text { Prob }>\text { F }\end{array}$ & \\
\hline Model & 6311.44 & 4 & 1577.86 & 692.14 & $<0.0001$ & \multirow[t]{6}{*}{ significant } \\
\hline B-Temperature & 18.91 & 1 & 18.91 & 8.30 & 0.0138 & \\
\hline C-Sludge, $\%$ & 4408.61 & 1 & 4408.61 & 1933.86 & $<0.0001$ & \\
\hline $\mathrm{BC}$ & 26.52 & 1 & 26.52 & 11.63 & 0.0052 & \\
\hline$C^{2}$ & 1857.40 & 1 & 1857.40 & 814.76 & $<0.0001$ & \\
\hline Residual & 27.36 & 12 & 2.28 & \multirow{4}{*}{4.83} & \multirow{4}{*}{0.0727} & \\
\hline Lack of Fit & 24.79 & 8 & 3.10 & & & \multirow[t]{3}{*}{$\begin{array}{c}\text { not } \\
\text { significant }\end{array}$} \\
\hline Pure Error & 2.57 & 4 & 0.64 & & & \\
\hline Cor Total & 6338.80 & 16 & & & & \\
\hline
\end{tabular}


Table 14. ANOVA table for $\mathrm{CH}_{4} \%$ for AD of spent grain and pot ale quadratic model $\alpha=0.05$.

\begin{tabular}{|c|c|c|c|c|c|c|}
\hline Source & Sum of Squares & $\mathrm{df}$ & Mean Square & F Value & $\begin{array}{c}p \text {-Value } \\
\text { Prob > F }\end{array}$ & \\
\hline Model & 3980.98 & 6 & 663.50 & 116.82 & $<0.0001$ & \multirow[t]{8}{*}{ significant } \\
\hline A-Beating Time & 129.82 & 1 & 129.82 & 22.86 & 0.0007 & \\
\hline B-Temperature & 189.33 & 1 & 189.33 & 33.34 & 0.0002 & \\
\hline C-Sludge & 2857.14 & 1 & 2857.14 & 503.06 & $<0.0001$ & \\
\hline $\mathrm{BC}$ & 132.08 & 1 & 132.08 & 23.26 & 0.0007 & \\
\hline $\mathrm{B}^{2}$ & 36.74 & 1 & 36.74 & 6.47 & 0.0292 & \\
\hline$C^{2}$ & 650.96 & 1 & 650.96 & 114.62 & $<0.0001$ & \\
\hline Residual & 56.80 & 10 & 5.68 & \multirow{4}{*}{2.95} & \multirow{4}{*}{0.1575} & \\
\hline Lack of Fit & 46.32 & 6 & 7.72 & & & \multirow{3}{*}{$\begin{array}{c}\text { not } \\
\text { significant }\end{array}$} \\
\hline Pure Error & 10.48 & 4 & 2.62 & & & \\
\hline Cor Total & 4037.77 & 16 & & & & \\
\hline
\end{tabular}

Table 15. ANOVA table for $\mathrm{CO}_{2} \%$ for AD of pot ale quadratic model $\alpha=0.05$.

\begin{tabular}{ccccccc}
\hline Source & Sum of Squares & df & Mean Square & F Value & $\begin{array}{c}p \text {-Value } \\
\text { Prob }>\text { F }\end{array}$ & \\
\hline Model & 1602.75 & 4 & 400.69 & 18.73 & $<0.0001$ & significant \\
B-Temperature & 65.55 & 1 & 65.55 & 3.06 & 0.1055 & \\
C-Sludge, $\%$ & 58.86 & 1 & 58.86 & 2.75 & 0.1230 & \\
BC & 155.00 & 1 & 155.00 & 7.25 & 0.0196 & \\
C $^{2}$ & 1323.34 & 1 & 1323.34 & 61.87 & $<0.0001$ & \\
Residual & 256.66 & 12 & 21.39 & & & not \\
Lack of Fit & 183.19 & 8 & 22.90 & 1.25 & 0.4433 & significant \\
Pure Error & 73.47 & 4 & 18.37 & & & \\
Cor Total & 1859.42 & 16 & &
\end{tabular}

Table 16. ANOVA table for $\mathrm{CO}_{2} \%$ for AD of spent grain and pot ale quadratic model $\alpha=0.05$.

\begin{tabular}{|c|c|c|c|c|c|c|}
\hline Source & Sum of Squares & df & Mean Square & F Value & $\begin{array}{l}p \text {-Value } \\
\text { Prob > F }\end{array}$ & \\
\hline Model & 803.08 & 4 & 200.77 & 24.11 & $<0.0001$ & \multirow[t]{6}{*}{ significant } \\
\hline B-Temperature & 18.30 & 1 & 18.30 & 2.10 & 0.1640 & \\
\hline C-Sludge & 351.13 & 1 & 351.13 & 42.17 & $<0.0001$ & \\
\hline $\mathrm{BC}$ & 37.21 & 1 & 37.21 & 4.47 & 0.0561 & \\
\hline$C^{2}$ & 396.45 & 1 & 396.45 & 47.61 & $<0.0001$ & \\
\hline Residual & 99.92 & 12 & 8.33 & \multirow{4}{*}{0.89} & \multirow{4}{*}{0.5923} & \\
\hline Lack of Fit & 63.86 & 8 & 7.98 & & & \multirow[t]{3}{*}{$\begin{array}{c}\text { not } \\
\text { significant }\end{array}$} \\
\hline Pure Error & 36.06 & 4 & 9.02 & & & \\
\hline Cor Total & 903.00 & 16 & & & & \\
\hline
\end{tabular}

For biogas yield, the first and the second order of sludge percentage $\left(C, C^{2}\right)$ were significant parameters regardless of feedstock type according to ANOVA. In case of AD of pot ale the first and second order of the beating time (A, $\left.\mathrm{A}^{2}\right)$ was found to be a significant parameter (Table 11) whereas in case of $\mathrm{AD}$ of spent grain and pot ale temperature (B) the interaction between temperature and sludge percentage (BC) were the significant factors (Table 12).

Final equations showed the biogas generation $(\mathrm{Y})$ as a function of the independent variables in terms of coded and actual factors on biogas production by AD of pot ale and spent grain and pot ale mixture given in Equations (2) and (3) and Equations (4) and (5) respectively.

Coded:

$$
\mathrm{Y}\left(\frac{\mathrm{ml}}{\mathrm{gVS}}\right)\{\text { pot ale }\}=208.74+26 \times \mathrm{A}+185.5 \times \mathrm{C}-37.16 \times \mathrm{A}^{2}+122.34 \times \mathrm{C}^{2}
$$




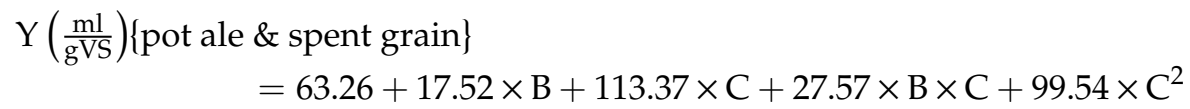

Actual:

$$
\begin{gathered}
\mathrm{Y}\left(\frac{\mathrm{ml}}{\mathrm{gVS}}\right)\{\text { pot ale }\} \\
=142.60+13.38 \times \text { Beating Time }-9.08 \times \text { Sludge } \%^{2} \\
\quad-0.66 \times \text { Beating Time }^{2}+0.31 \times \text { Sludge } \%{ }^{2} \\
\mathrm{Y}\left(\frac{\mathrm{ml}}{\mathrm{gVS}}\right)\{\text { pot ale \& spent grain }\} \\
=395.14-7.94 \times \text { Temperature }-25.34 \times \text { Sludge } \% \\
+0.46 \times \text { Temerature } \times \text { Sludge } \%+0.25 \times \text { Sludge } \%{ }^{2}
\end{gathered}
$$

The coefficients of the final equation in terms of coded factors (Equations (2) and (3)) indicates the power of the design parameters on biogas generation as $C>C^{2}>A^{2}>A$ and $C>C^{2}>B C>B$ for $A D$ of pot ale and spent grain pot ale mixture.

ANOVA results for $\mathrm{CH}_{4} \%$ modelling, showed the digestion temperature (B), the first and second order effects of sludge $\left(C, C^{2}\right)$, as well as interaction between temperature and sludge percentage $(B C)$ as significant parameters for $\mathrm{AD}$ of pot ale in $95 \%$ confidence interval (Table 13).The beating time (A), first and the second order effects of temperature $\left(B, B^{2}\right)$ and sludge $\%\left(C, C^{2}\right)$, as well as the interaction effect of temperature and sludge percentage $(\mathrm{BC})$ were the significant model terms for AD spent grain and pot ale mixture (Table 14). Influence strength of the significant parameters on $\mathrm{CH}_{4}$ concentration within the biogas generated by $\mathrm{AD}$ of pot ale and pot ale and spent grain mixture was identified as $\mathrm{C}>$ $\mathrm{C}^{2}>\mathrm{BC}>\mathrm{B}$ and $\mathrm{C}>\mathrm{C}^{2}>\mathrm{BC}>\mathrm{B}>\mathrm{A}>\mathrm{B}^{2}$ respectively by considering coefficient of the final equation in terms of coded factors Equations (6) and (7). The final models in terms of actual factors are given in Equations (8) and (9) for AD of pot ale and AcoD of spent grain and pot ale mixture respectively.

Coded:

$$
\mathrm{CH}_{4}(\%)\{\text { pot ale }\}=3.93+1.54 \times \mathrm{B}+23.48 \times \mathrm{C}+2.57 \times \mathrm{B} \times \mathrm{C}+20.94 \times \mathrm{C}^{2}
$$

$\mathrm{CH}_{4}(\%)\{$ pot ale \& spent grain $\}=12.98+4.03 \times \mathrm{A}+4.86 \times \mathrm{B}+18.90 \times \mathrm{C}+5.75 \times \mathrm{B} \times \mathrm{C}-2.95 \times \mathrm{B}^{2}+12.42 \times \mathrm{C}^{2}$

Actual:

$$
\begin{aligned}
& \mathrm{CH}_{4}(\%)\{\text { pot ale }\}=42.96-0.78 \times \text { Temperature }-3.47 \times \text { Sludge } \% \\
& +0.043 \text { Temperature } \times \text { Sludge } \%+0.05 \times \text { Sludge } \%{ }^{2}
\end{aligned}
$$

$\mathrm{CH}_{4}(\%)\{$ pot ale \& spent grain $\}=-349.18+0.54 \times$ Beating Time $+21.69 \times$ Temperature $-4.27 \times$ Sludge $\%+0.10 \times$ Temperature $\times$ Sludge $\%-0.33 \times$ Temperature $^{2}+0.031 \times$ Sludge $^{2}{ }^{2}$

For modelling $\mathrm{CO}_{2}$ concentrations, ANOVA analysis defined the second order effect of sludge $\%$ $\left(\mathrm{C}^{2}\right)$ and the interaction between temperature and sludge percentage $(\mathrm{BC})$ as significant model terms within a $95 \%$ confidence interval for AD of pot ale (Table 15). The first order effects of temperature (B) and sludge $\%(\mathrm{C})$ were added to the model by the software to support hierarchy. The first and second order effects of sludge percentages $\left(C, C^{2}\right)$ were the significant parameters for $\mathrm{CO}_{2}$ modelling by $\mathrm{AD}$ of spent grain and pot ale mixture (Table 16). However, temperature (B) and the interaction effect of temperature and sludge $\%(\mathrm{BC})$ were also added to the model after the stepwise regression to improve the model by the software. The strength of the model terms on $\mathrm{CO}_{2}$ content of generated biogas by $\mathrm{AD}$ pot ale and spent grain pot ale mixture was defined as $C^{2}>B C>B>C$ and $C^{2}>C>B C>B$ based on the coefficient of the final equation in terms of coded factor (Equations (10) and (11)). The final mathematical models on $\mathrm{CO}_{2}$ content of produced biogas are given in Equations (12) and (13).

Coded:

$$
\mathrm{CO}_{2}(\%)\{\text { pot ale }\}=40.69-2.86 \times \mathrm{B}+2.71 \times \mathrm{C}+6.22 \times \mathrm{B} \times \mathrm{C}-17.68 \times \mathrm{C}^{2}
$$


$\mathrm{CO}_{2}(\%)\{$ pot ale \& spent grain $\}=55.90-1.52 \times \mathrm{B}-6.64 \times \mathrm{C}-3.03 \times \mathrm{B} \times \mathrm{C}-9.67 \times \mathrm{C}^{2}$

Actual:

$$
\begin{aligned}
& \mathrm{CO}_{2}(\%)\{\text { pot ale }\}=139.18-4.07 \times \text { Temperature }-0.84 \times \text { Sludge } \% \\
& +0.10 \times \text { Temperature } \times \text { Sludge } \%-0.044 \times \text { Sludge } \%{ }^{2}
\end{aligned}
$$

$$
\begin{aligned}
& \mathrm{CO}_{2}(\%)\{\text { pot ale \& spent grain }\}=8.70+1.01 \times \text { Temperature }+2.89 \times \text { Sludge } \% \\
& -0.05 \times \text { Temperature } \times \text { Sludge } \%-0.02 \times \text { Sludge } \%^{2}
\end{aligned}
$$

\subsection{Validation of the Estimated Models}

The diagnosis of the estimated models was performed by the same software as part of the post statistical analysis. The diagnostic plots, the normal plot of residuals and the predicted vs. actual plot for $\mathrm{AD}$ of pot ale, are given in Figures 6 and 7 respectively.

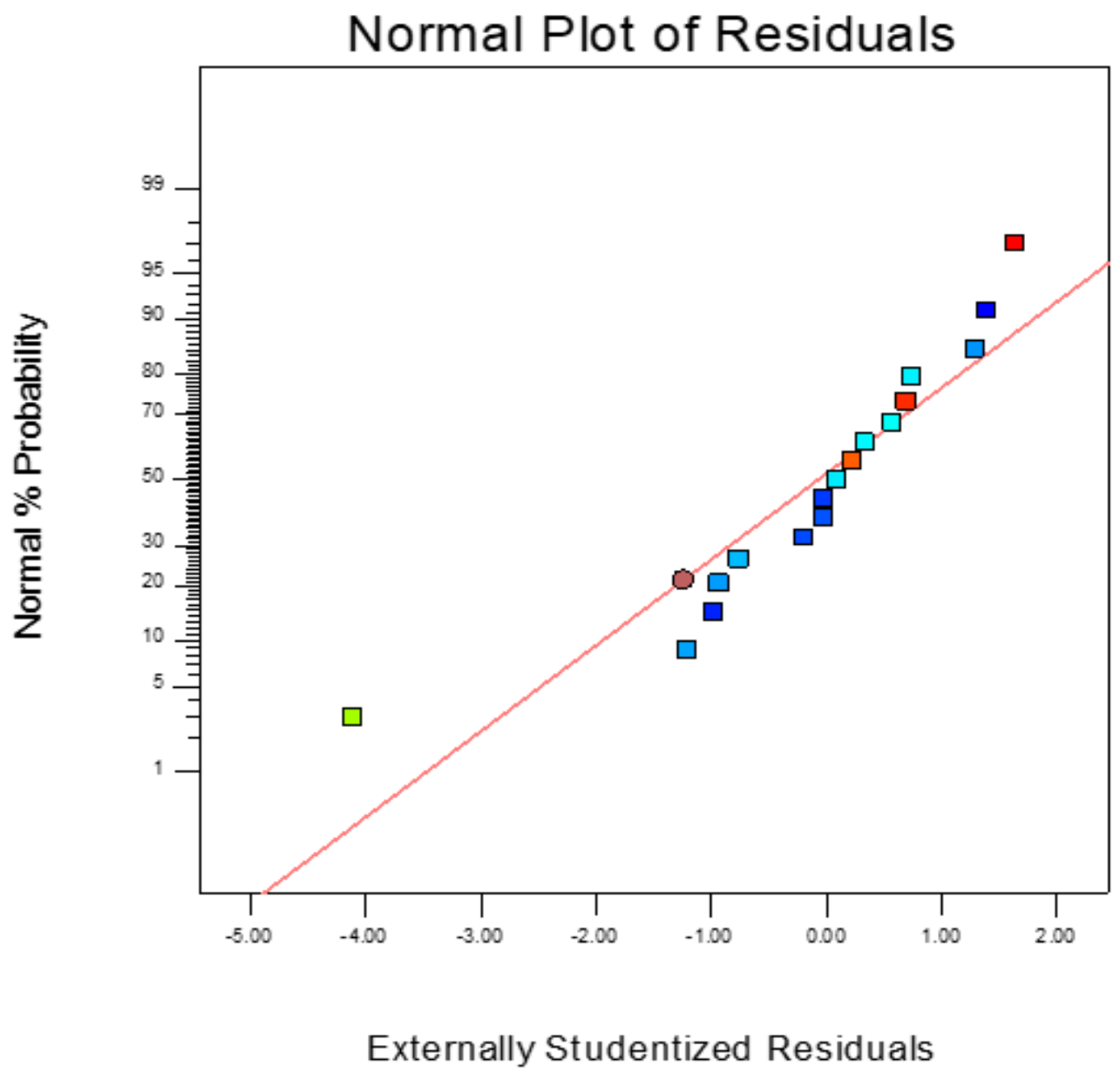

Figure 6. Normal plot of residuals on biogas generation (ml/g VS) for AD of pot ale.

The normal distribution of residual data in Figure 6 proves that ANOVA can be applied to the dataset. Figure 7 gives the comparison between the actual data set and the predicted data set by developed model. It is seen that the residuals are minimum since all the design points tend to be close to the diagonal line. The developed mathematical model is therefore adequate. The similar trend in both normal plot of residuals and actual vs. predicted plot is seen for the built models on $\mathrm{CH}_{4}$ and $\mathrm{CO}_{2}$ percentages for $\mathrm{AD}$ pot ale as well as all models developed for $\mathrm{AD}$ of spent grain and pot ale mixture. 


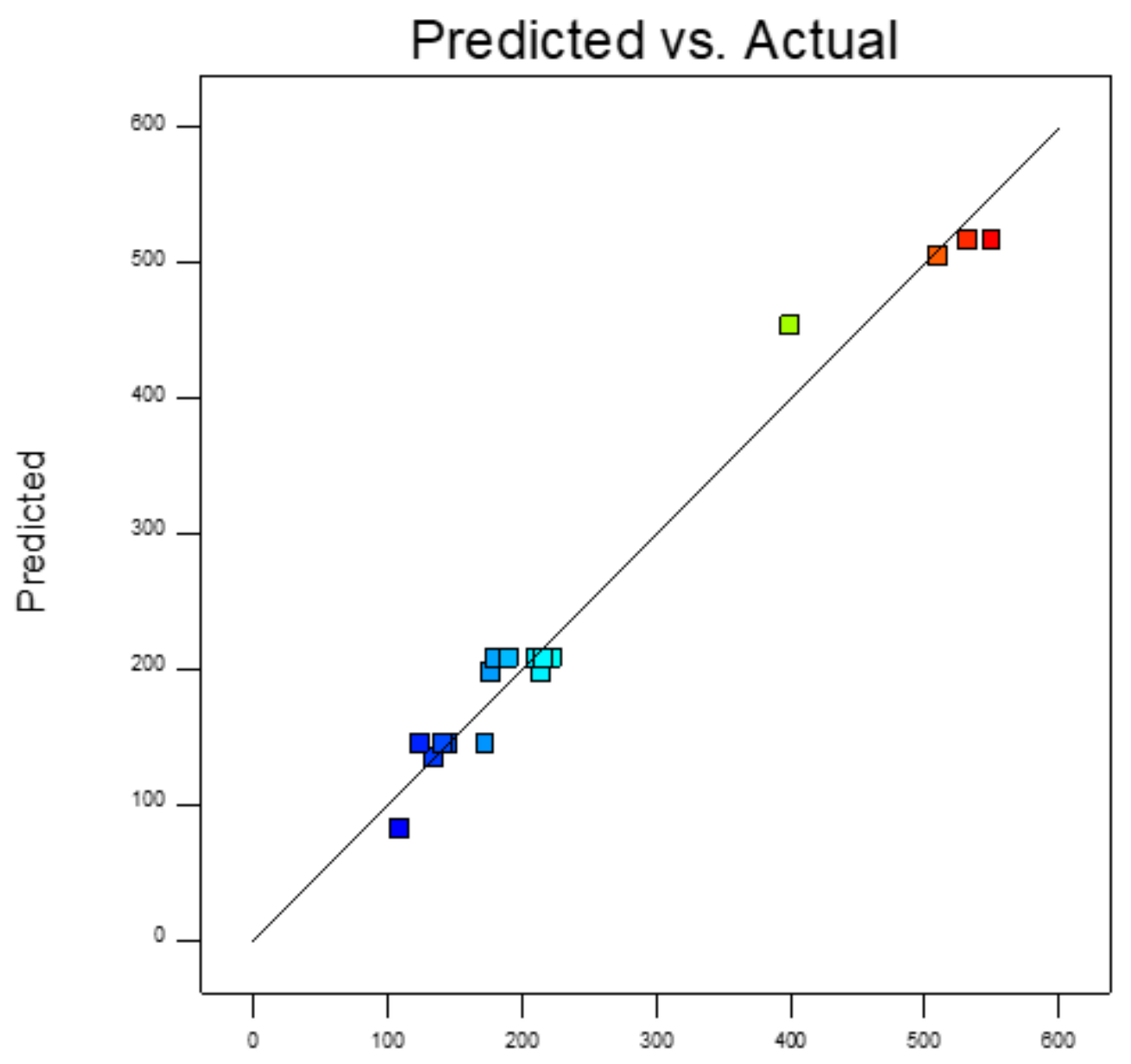

Actual

Figure 7. Scatter diagram biogas generation (ml/g VS) for AD of pot ale.

In addition to post analysis, the models were challenged by independent experiments for a further validation step. Three validation points for validating the models on AD of pot ale and two validation points for validating models on $\mathrm{AD}$ pot ale and spent grain (which were not used for model development) were decided and the results of the experiments were given in Tables 17 and 18 respectively along with the predicted values by the models in terms of actual factors for each interest of response. The Equations (4), (8), and (12) were used to predict the results, given in Table 17, of the validation for biogas yield, $\mathrm{CH}_{4} \%$ and $\mathrm{CO}_{2} \%$ by $\mathrm{AD}$ of pot ale respectively. Likewise, the Equations (5), (9), and (13) were used for the predictions, given in Table 18 on biogas yield, $\mathrm{CH}_{4} \%$ and $\mathrm{CO}_{2} \%$ respectively though $\mathrm{AD}$ of spent grain and pot ale mix. The difference between the predicted and the experimental results were then statistically analysed by $t$-test (2-tailed distribution with unequal variance). The modelling of the biogas quality and the quantity was validated for both designs within a 95\% confidence interval in accordance according to the $p$-values in Tables 17 and 18 . 
Table 17. Validation experiment results versus predicted results for AD of pot ale.

\begin{tabular}{|c|c|c|c|c|c|c|}
\hline \multirow[t]{2}{*}{ Validation Points } & \multicolumn{2}{|c|}{ Biogas Yield (ml/g VS) } & \multicolumn{2}{|c|}{$\mathrm{CH}_{4} \%$} & \multicolumn{2}{|c|}{$\mathrm{CO}_{2} \%$} \\
\hline & Experimental & Predicted & Experimental & Predicted & Experimental & Predicted \\
\hline \multirow[t]{2}{*}{ 0B $50 \% \mathrm{~S} 38^{\circ} \mathrm{C}$} & $464 \pm 26$ & 532 & $54.2 \pm 9$ & 46.5 & $33.1 \pm 10$ & 22.5 \\
\hline & \multicolumn{2}{|c|}{$p: 0.672$} & \multicolumn{2}{|c|}{$p: 1.000$} & \multicolumn{2}{|c|}{$p: 0.226$} \\
\hline \multirow[t]{2}{*}{ 0B $10 \% \mathrm{~S} 38^{\circ} \mathrm{C}$} & $91 \pm 11$ & 83 & $1.2 \pm 0.2$ & 0.4 & $33.3 \pm 10.4$ & 9.7 \\
\hline & \multicolumn{2}{|c|}{$p: 0.327$} & \multicolumn{2}{|c|}{$p: 0.084$} & \multicolumn{2}{|c|}{$p: 0.059$} \\
\hline \multirow[t]{2}{*}{ 0B $30 \% \mathrm{~S} 35^{\circ} \mathrm{C}$} & $167 \pm 14$ & 149 & $9.0 \pm 2.4$ & 4.71 & $50.8 \pm 6.9$ & 36.9 \\
\hline & \multicolumn{2}{|c|}{$p: 0.155$} & \multicolumn{2}{|c|}{$p: 0.089$} & \multicolumn{2}{|c|}{$p: 0.075$} \\
\hline
\end{tabular}

Table 18. Validation experiment results versus predicted results for AD of spent grain and pot ale mix.

\begin{tabular}{|c|c|c|c|c|c|c|}
\hline \multirow[t]{2}{*}{ Validation Points } & \multicolumn{2}{|c|}{ Biogas Yield (ml/g VS) } & \multicolumn{2}{|c|}{$\mathrm{CH}_{4} \%$} & \multicolumn{2}{|c|}{$\mathrm{CO}_{2} \%$} \\
\hline & Experimental & Predicted & Experimental & Predicted & Experimental & Predicted \\
\hline \multirow[t]{2}{*}{ 0B $50 \% \mathrm{~S} 38^{\circ} \mathrm{C}$} & $378 \pm 84$ & 325 & $44.2 \pm 7.3$ & 52 & $40.1 \pm 12$ & 46.5 \\
\hline & \multicolumn{2}{|c|}{$p: 0.391$} & \multicolumn{2}{|c|}{$p: 0.207$} & \multicolumn{2}{|c|}{$p: 0.479$} \\
\hline \multirow[t]{2}{*}{ 0B $10 \% \mathrm{~S} 38^{\circ} \mathrm{C}$} & $78 \pm 35$ & 40 & $2.2 \pm 0.8$ & 1.1 & $62.7 \pm 12.6$ & 54.9 \\
\hline & \multicolumn{2}{|c|}{$p: 0.202$} & \multicolumn{2}{|c|}{$p: 0.161$} & \multicolumn{2}{|c|}{$p: 0.399$} \\
\hline
\end{tabular}

\subsection{Model Graphs}

The perturbation plots give the effect of all factors, which have different units, on the same graph since it is plotted in terms of coded factors. The lines show the individual behaviour of each factor while keeping the other at a constant ratio (their centre points by default). It can be used to identify which factor affects the response of interest the most. Figure 8a-c and $\mathrm{d}-\mathrm{f}$ shows the perturbation graphs for biogas yield, $\mathrm{CH}_{4} \%$ and $\mathrm{CO}_{2} \%$ for $\mathrm{AD}$ of pot ale and $\mathrm{AcoD}$ of spent grain pot ale mix respectively. In both cases, the curvature related to the sludge percentages $(C)$ showed that this factor had a greater impact on the response than the beating time (A) and the digestion temperature (B). Although results were different, the digestion temperature $(\mathrm{B})$ and the sludge ratio $(\mathrm{C})$ had similar effects on $\mathrm{CH}_{4} \%$ and $\mathrm{CO}_{2} \%$ for both DOE experiments (Figure $8 \mathrm{~b}, \mathrm{e}$ ) and Figure $8 \mathrm{c}$, f respectively.

Figure $9 \mathrm{a}-\mathrm{c}$ and $\mathrm{d}-\mathrm{f}$ give the contour graphs for biogas yield, $\mathrm{CH}_{4} \%$ and $\mathrm{CO}_{2} \%$ for $\mathrm{AD}$ of pot ale and $\mathrm{AcoD}$ of spent grain pot ale mix respectively. The effects of temperature and sludge percentages mainly have straight lines on all responses. However, a peak was seen for the area around $20-30 \%$ sludge for biogas yield, $\mathrm{CH}_{4}$ and $\mathrm{CO}_{2} \%$ for AcoD of spent grain and pot ale (Figure $9 \mathrm{~d}-\mathrm{f}$ ) as well as $\mathrm{CO}_{2 \%}$ of the biogas produced by $\mathrm{AD}$ of pot ale (Figure 9c). In both experiments, the greatest biogas generation and the highest $\mathrm{CH}_{4}$ percentage are achieved under the condition of higher sludge seeding ratio and digestion temperature, while the same conditions resulted in lower $\mathrm{CO}_{2} \%$.

There was no interaction between the factors for the model developed on biogas yield for AD of pot ale. The interactions between the sludge percentages and the digestion temperatures for the quality of biogas produced by $\mathrm{AD}$ of pot ale is given in Figure 10a,b along with the interactions for biogas yield $\mathrm{CH}_{4}$ and $\mathrm{CO}_{2}$ percentages for AcoD for spent grain pot ale. The digestion temperature had no significant influence at low sludge seeding ratios $(<20 \%)$. However, once the sludge ratio was increased, the digestion at $38^{\circ} \mathrm{C}$ has significantly increased the biogas production by AcoD of spent grain and pot ale and its $\mathrm{CH}_{4}$ content (Figure 10c,d) as well as the biogas quality of AD of pot ale (Figure 10a). In contrast, a completely opposite interaction was seen on $\mathrm{CO}_{2}$ contents of the biogas produced by $\mathrm{AD}$ of pot ale and AcoD of spent grain pot ale mix. Digestion at $38^{\circ} \mathrm{C}$ had a significantly lower $\mathrm{CO}_{2} \%$ within the biogas produced by $\mathrm{AD}$ of pot ale (Figure 10b). However, the effect of digestion temperature on it became insignificant once the sludge seeding ratio is increased. An opposite figure was seen on $\mathrm{CO}_{2}$ content of for AcoD of spent grain pot ale (Figure 10e). 

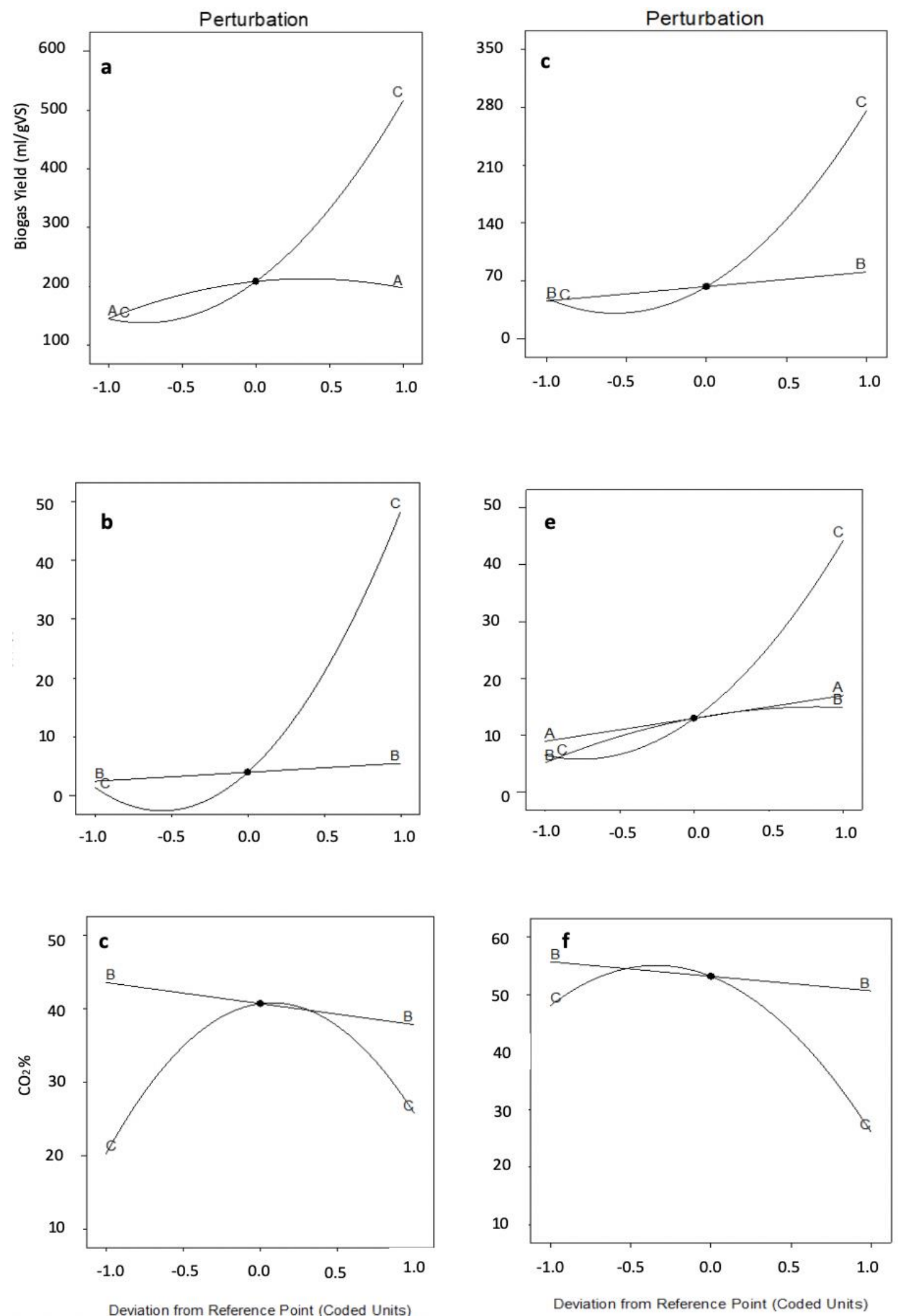

Figure 8. Perturbation graphs for $\mathrm{AD}$ of pot ale and spent grain pot ale mix on biogas yield (a,d), $\mathrm{CH} 4 \%$ $(\mathbf{b}, \mathbf{e})$, and $\mathrm{CO}_{2} \%(\mathbf{c}, \mathbf{f})$ respectively. 

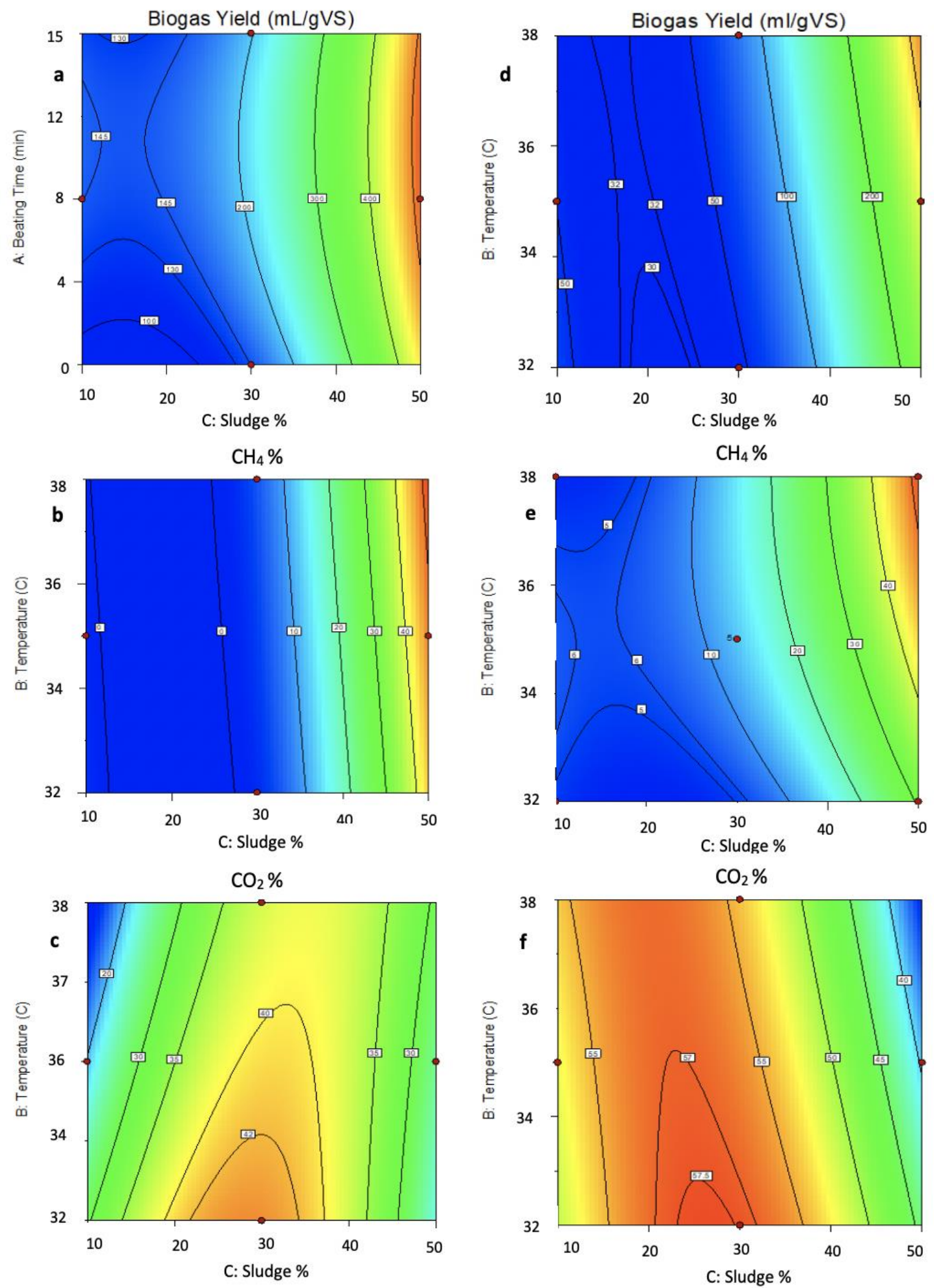

Figure 9. Contour graphs for $\mathrm{AD}$ of pot ale and spent grain pot ale mix on biogas yield (a,d), $\mathrm{CH}_{4} \%$ $(\mathbf{b}, \mathbf{e})$, and $\mathrm{CO}_{2} \%(\mathbf{c}, \mathbf{f})$ respectively. 

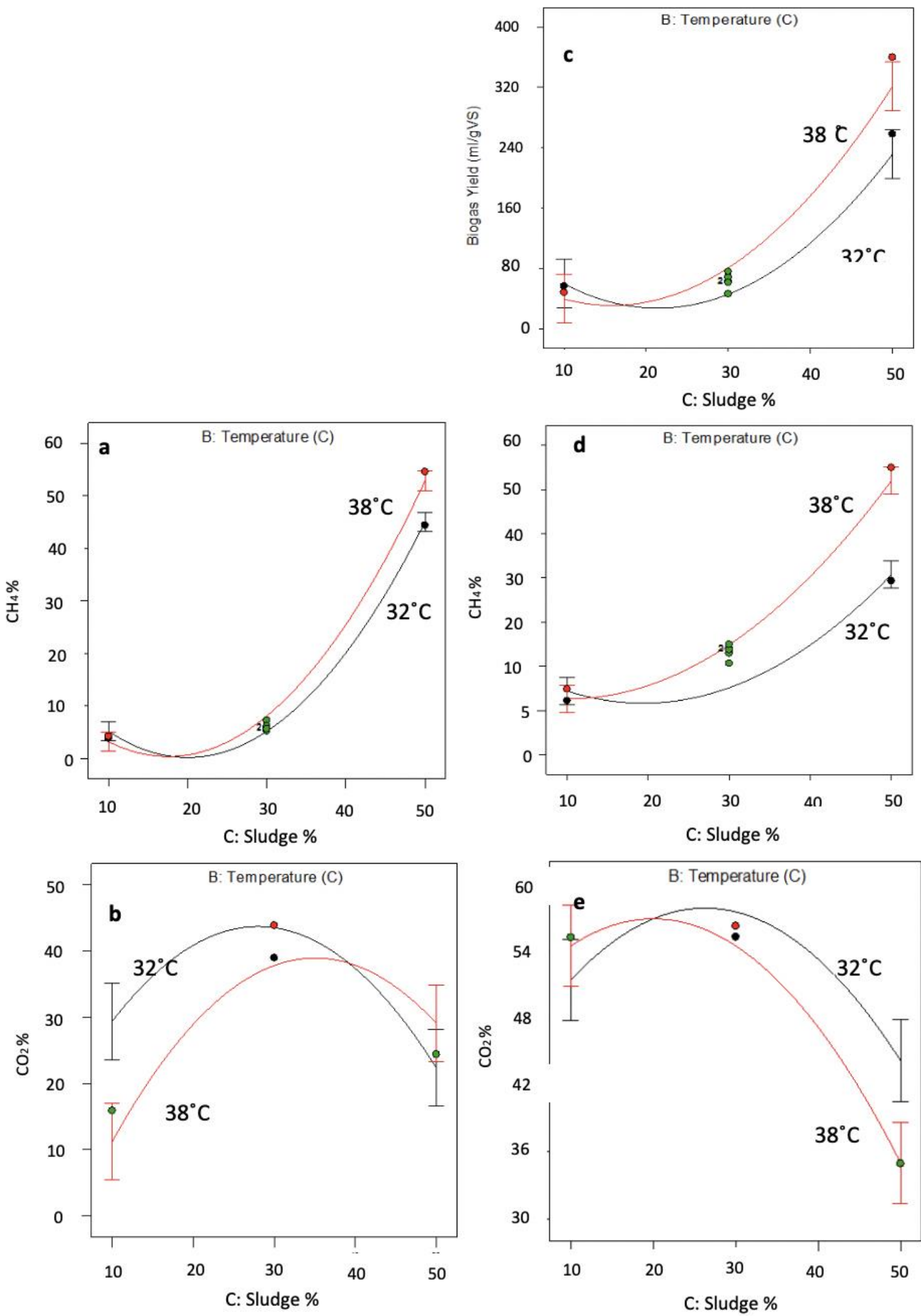

Figure 10. Interaction graphs for $\mathrm{AD}$ of pot ale and spent grain and pot ale mix on $\mathrm{CH}_{4} \%(\mathbf{a}, \mathbf{d})$ and $\mathrm{CO}_{2} \%(\mathbf{b}, \mathbf{e})$ respectively and on biogas yield by $\mathrm{AD}$ of pot ale spent grain (c). 


\subsection{Optimisation of the Developed Models}

The design factors were kept in range however biogas yield and $\mathrm{CH}_{4} \%$ were maximised with the importance of 5 whereas $\mathrm{CO}_{2} \%$ was minimised with the same importance level. The optimisation conditions for $\mathrm{AD}$ pot ale and spent grain and pot ale mix are outlined in Tables 19 and 20 respectively. Corresponding suggested solutions are given in Tables 21 and 22 respectively. The first solutions were selected based on its higher desirability to define lower and upper limits of graphical optimisation.

Table 19. Optimisation conditions for AD pot ale.

\begin{tabular}{ccccc}
\hline Variable & Goal & Lower Limit & Upper Limit & Importance \\
\hline A: Beating Time $(\mathrm{min})$ & is in range & 0 & 15 & 3 \\
B: Temperature $\left({ }^{\circ} \mathrm{C}\right)$ & is in range & 32 & 38 & 3 \\
C: Sludge $(\%)$ & is in range & 10 & 50 & 3 \\
Biogas Yield $(\mathrm{ml} / \mathrm{g}$ VS) & maximize & 109 & 550 & 5 \\
$\mathrm{CH}_{4} \%$ & maximize & 1 & 54.3 & 5 \\
$\mathrm{CO}_{2} \%$ & minimize & 13.2 & 48.4 & 5 \\
\hline
\end{tabular}

Table 20. Optimisation conditions for AD pot ale and spent grain mix.

\begin{tabular}{ccccc}
\hline Variable & Goal & Lower Limit & Upper Limit & Importance \\
\hline A: Beating Time $(\mathrm{min})$ & is in range & 0 & 15 & 3 \\
B: Temperature $\left({ }^{\circ} \mathrm{C}\right)$ & is in range & 32 & 38 & 3 \\
$\mathrm{C}:$ Sludge $(\%)$ & is in range & 10 & 50 & 3 \\
Biogas Yield (ml/g VS) & maximize & 42.5 & 359.9 & 5 \\
$\mathrm{CH}_{4} \%$ & maximize & 2.2 & 55.0 & 5 \\
$\mathrm{CO}_{2} \%$ & minimize & 35.0 & 59.1 & 5 \\
\hline
\end{tabular}

Table 21. Numerical optimisation solutions for AD of pot ale.

\begin{tabular}{cccccccc}
\hline No. & $\begin{array}{c}\text { A: Beating } \\
\text { Time (min) }\end{array}$ & $\begin{array}{c}\text { B: Temperature } \\
\left({ }^{\circ} \mathbf{C}\right)\end{array}$ & C: Sludge $\%$ & $\begin{array}{c}\text { Biogas Yield } \\
(\mathbf{m l} / \mathbf{g} \text { VS) }\end{array}$ & $\mathbf{C H}_{\mathbf{4}} \%$ & $\mathbf{C O}_{\mathbf{2}} \%$ & Desirability \\
\hline 1 & 10.14 & 32.00 & 50.00 & 521.13 & 44.24 & 22.36 & 0.82 \\
2 & 7.65 & 32.00 & 50.00 & 517.08 & 44.24 & 22.36 & 0.81 \\
3 & 9.96 & 35.01 & 50.00 & 521.11 & 48.37 & 25.74 & 0.80 \\
4 & 11.76 & 34.94 & 50.00 & 519.37 & 48.27 & 25.66 & 0.80 \\
5 & 7.81 & 36.15 & 50.00 & 517.59 & 49.92 & 27.01 & 0.79 \\
\hline
\end{tabular}

Table 22. Numerical optimisation solutions for $\mathrm{AD}$ of pot ale and spent grain mix.

\begin{tabular}{cccccccc}
\hline No. & $\begin{array}{c}\text { A: Beating } \\
\text { Time (min) }\end{array}$ & $\begin{array}{c}\text { B: Temperature } \\
\left({ }^{\circ} \mathbf{C}\right)\end{array}$ & C: Sludge $\%$ & $\begin{array}{c}\text { Biogas Yield } \\
(\mathbf{m l} / \mathbf{g} \text { VS) }\end{array}$ & $\mathbf{C H}_{\mathbf{4}}$ \% & $\mathbf{C O}_{\mathbf{2}}$ \% & Desirability \\
\hline 1 & 13.09 & 38.00 & 50.00 & 321.21 & 54.95 & 35.05 & 0.96 \\
2 & 11.06 & 38.00 & 50.00 & 321.25 & 53.87 & 35.04 & 0.96 \\
3 & 8.69 & 38.00 & 50.00 & 321.25 & 52.59 & 35.04 & 0.95 \\
4 & 15.00 & 37.09 & 50.00 & 307.64 & 54.30 & 36.42 & 0.93 \\
5 & 15.00 & 35.66 & 49.93 & 285.02 & 50.36 & 38.68 & 0.84 \\
\hline
\end{tabular}

The graphical optimisation of AD of pot ale and spent grain pot ale mix is given in Figure 11a,b respectively. The target area coloured with yellow is delimited by constraints set according to the numerical optimisation solutions (Tables 21 and 22). For example, in the case of AD of pot ale, lower and upper limits of the optimum area are 520 and $521 \mathrm{~mL} / \mathrm{g}$ vs. for biogas generation with 22 and $24 \%$ for $\mathrm{CO}_{2}$ content. In the case of $\mathrm{CH}_{4} \%$, only the lower limit (48.3\%) is visible on the chart because the lower limit does not overlap with the other criteria. In the case of $\mathrm{AD}$ of spent grain, pot ale mix defining lines for the target area are $317.03 \mathrm{~mL} / \mathrm{g}$ vs. biogas production, $53.2 \mathrm{CH}_{4}$ and $36 \% \mathrm{CO}_{2}$ percentages. 

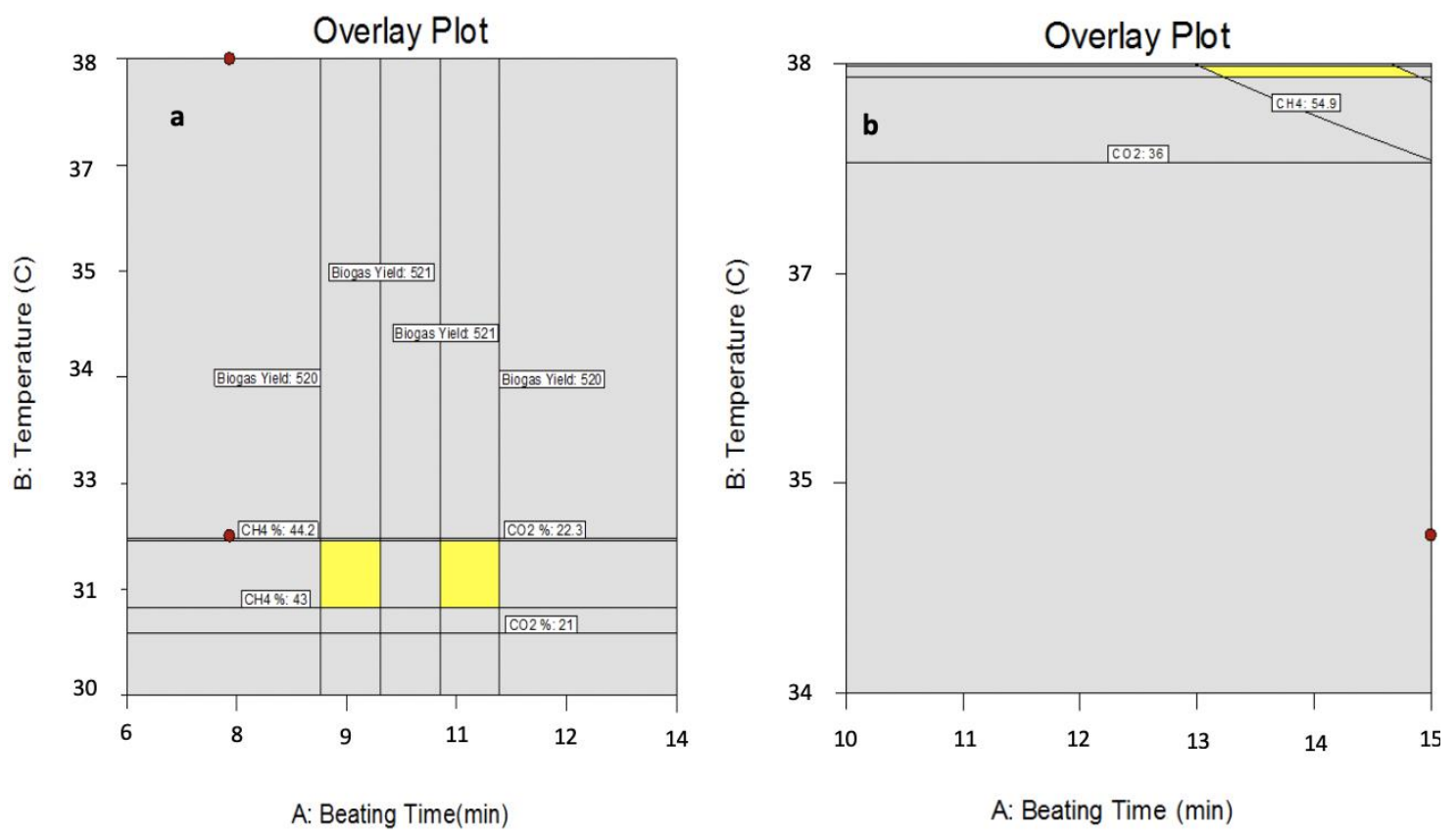

Figure 11. Graphical optimisation for AD of pot ale (a) and AD of spent grain pot ale mix (b).

\section{Discussion}

The characteristics of non-treated pot ale were mainly found to be in agreement with the literature in terms of the concentrations of COD $(38,867 \pm 115 \mathrm{mg} / \mathrm{L}), \mathrm{BOD}(30,965 \pm 666 \mathrm{mg} / \mathrm{L}), \mathrm{SO}_{4}(190 \pm 31 \mathrm{mg} / \mathrm{L})$ within the reported ranges 30,000-50,000 mg/L for COD [61-64], 25,000-35,000 mg/L for BOD [49,64,65], and $223-284.8 \mathrm{mg} / \mathrm{L}$ for $\mathrm{SO}_{4}$ [66]. The $\mathrm{pH}$ (3.7) was also within the reported range of 3.5-4.5 [67,68]. A slight difference was found between the concentrations of $\mathrm{PO}_{4}{ }^{3-}(778 \pm 7 \mathrm{mg} / \mathrm{L}), \mathrm{N}^{3} \mathrm{NH}_{3}(45 \pm 7 \mathrm{mg} / \mathrm{L})$, $\mathrm{N}-\mathrm{NO}_{3}(111 \pm 20 \mathrm{mg} / \mathrm{L}), \mathrm{N}-\mathrm{NO}_{2}(33 \pm 4 \mathrm{mg} / \mathrm{L})$, and $\mathrm{Cu}(14.7 \pm 1 \mathrm{mg} / \mathrm{L})$ and the corresponding reported concentrations: $714 \mathrm{mg} / \mathrm{L}[63,69]$ for $\mathrm{PO}_{4}{ }^{3-}, 0.12-7.9 \mathrm{mg} / \mathrm{L}$ for N-NH 3 [70], 8.3-53 mg/L for $\mathrm{N}_{-} \mathrm{NO}_{3}$, $16-20 \mathrm{mg} / \mathrm{L}$ for $\mathrm{N}_{-} \mathrm{NO}_{2}$, and 2-6 mg/L for $\mathrm{Cu}$ [64]. These differences were attributed to use of different source of raw materials and process parameters of the sampling distillery. Biogas yield and quality obtained from $\mathrm{AD}$ of whiskey distillery/brewery waste streams (pot ale and spent grain pot ale mix) was examined using lab scale batch experiments. The effect of alkaline pre-treatment $(1 \mathrm{M} \mathrm{NaOH})$ on the lignocellulosic structure of pot ale and spent grain was found to be a significant parameter on lignin degradation as well as on hemicellulose solubilisation which was then associated with overall $\mathrm{AD}$ performance. A hybrid alkaline and beating pre-treatment was introduced. In order to assess the efficiency of the digestion, organic matter removals in terms of COD and BOD were measured before and after $\mathrm{AD}$, while the potential bacterial competition between acetoclastic methanogenic archaea and sulphate reducing bacteria was traced with $\mathrm{SO}_{4}$ removal. Up to $78 \pm 5 \% \mathrm{COD}$ and $61 \pm 4 \% \mathrm{BOD}$ removals were achieved by $\mathrm{AD}$ of pot ale along with $25 \pm 1 \% \mathrm{SO}_{4}$ degradation, while COD and BOD removals up to $73 \pm 6$ and $63 \pm 7 \%$ respectively were achieved by AcoD of spent grain and pot ale along with a $31 \pm 7 \mathrm{SO}_{4}$ removal. The maximum biogas yields of $629 \pm 8.5 \mathrm{~mL} / \mathrm{g}$ vs. with a $51.3 \%$ $\mathrm{CH}_{4}$ content (Table 3) and $360 \pm 10 \mathrm{~mL} / \mathrm{g}$ vs. with a $55.0 \pm 0.4 \mathrm{CH}_{4} \%$ content (std. 12 in Table 8) over 21 days of digestion period was achieved for samples subjected to alkaline and subsequent $7.5 \mathrm{~min}$ beating pre-treatments; seeded with 1:1 sludge ratio on wet basis at 35 (for pot ale) and $38^{\circ} \mathrm{C}$ (for pot ale and spent grain) digestion temperature. A methane yield of $554 \pm 67 \mathrm{~mL} / \mathrm{g}$ vs. was reported by [70] with $\mathrm{AD}$ of non-treated pot ale with a substrate inoculum ratio of 1:2 (on wet basis) at lab scale batch experiments, while in this study the highest methane yield was found as $322 \pm 4 \mathrm{~mL} / \mathrm{g}$ vs. (Table 3) by $\mathrm{AD}$ of alkaline and $7.5 \mathrm{~min}$ beating pre-treated pot ale with a substrate to inoculum ratio of 1:1. The difference between the two yields was attributed to the lower inoculum ratio in the experiments as the reactor configurations and alkali conditions were similar in both works. The efficiency of AD 
was evaluated based on the removal of organic matter by the treatment and various COD and BOD degradations have been reported for different reactor configurations and pre-treatment conditions for AD of pot ale. During the first 140 days of digestion, a typical COD removal was reported as 70-90\% by AD of alkaline $\left(\mathrm{NaHCO}_{3}\right)$ pre-treated pot ale using a UASB [61]. Enhanced levels of COD (96\%) and BOD (99\%) removals were obtained by [63] for AD of pot ale with addition of $\mathrm{NaHCO}_{3}$ and nutrient supplement for accelerated growth of culture using two stage UASB. On the other hand, 13 and 50\% COD reductions were obtained by AD of pot ale without and with enzymatic pre-treatment using $10 \%$ papain in a lab scale batch reactor [67]. In this work, the highest levels of organic matter removals $(78 \pm 5 \%$ for COD and $61 \pm 4 \%$ for BOD) were seen in AD of pot ale (std. no. 8 in Table 7 ), it was slightly higher than co-digestion of pot ale and draff mixture. Organic degradation rates were found to be in an agreement with published works [61,67].

The sludge percentages had the biggest impact on all responses according to the perturbation plots given Figure 8 as well as the mathematical models in terms of coded factors. Sludge percentage was found to be the most powerful factor on interest of responses. Therefore, samples containing low sludge percentage (10 and 30\%) had low biogas generation and methane quality regardless of the pre-treatment. The optimum digestion conditions were identified as 10- and 13-min beating times, 32 and $38{ }^{\circ} \mathrm{C}$ digestion temperature for $\mathrm{AD}$ of pot ale and $\mathrm{AcoD}$ of spent grain pot ale mixture respectively as well as $50 \%$ sludge seeding ratio for both cases.

Author Contributions: Conceptualization, B.G., P.D., C.C., and J.L.; Data curation, M.C.; Formal analysis, B.G., K.B. and J.L.; Funding acquisition, P.D., C.C., and J.L.; Investigation, B.G., M.C., C.C., and J.L.; Methodology, B.G., K.B., J.S., P.D., C.C., and J.L.; Project administration, J.L.; Resources, C.C.; Supervision, J.S., P.D., C.C., and J.L.; Visualization, K.B.; Writing—original draft, B.G.; Writing—review and editing, J.S., P.D., C.C., and J.L. All authors have read and agreed to the published version of the manuscript.

Funding: This project was fully funded by Alltech Ireland Ltd., Project ID 15-S-ST-10568.

Acknowledgments: The authors acknowledge the immense support of Alltech Ireland Ltd. for funding the project and for unwavering support. The authors are most grateful to Brian Fay and Indre Sinkunaite at Alltech Ltd. for their help in analysis to produce relevant data. The internship of Maxime Carrié was funded with the support of the Erasmus+ programme of the European Union.

Disclaimer: The European Commission support for the production of this publication does not constitute an endorsement of the contents which reflects the views only of the authors, and the Commission cannot be held responsible for any use which may be made of the information contained therein.

Conflicts of Interest: The authors declare no conflict of interest.

\section{References}

1. Bundhoo, M.A.Z.; Mohee, R.; Hassan, M.A. Effects of pre-treatment technologies on dark fermentative biohydrogen production: A review. J. Environ. Manag. 2015, 157, 20-48. [CrossRef] [PubMed]

2. Cuellar, A.D.; Herzog, H. A Path Forward for Low Carbon Power from Biomass. Energies 2015, 8, 1701-1715. [CrossRef]

3. Bryngelsson, D.; Wirsenius, S.; Hedenus, F.; Sonesson, U. How can the EU climate targets be met? A combined analysis of technological and demand-side changes in food and agriculture. Food Policy 2016, 59, 152-164. [CrossRef]

4. Cesaro, A.; Belgiorno, V. Pretreatment methods to improve anaerobic biodegradability of organic municipal solid waste fractions. Chem. Eng. J. 2014, 240, 24-37. [CrossRef]

5. Saady, N.M.C.; Massé, D.I. Impact of Organic Loading Rate on Psychrophilic Anaerobic Digestion of Solid Dairy Manure. Energies 2015, 8, 1990-2007. [CrossRef]

6. Ramachandran, A.; Rustum, R.; Adeloye, A.J. Review of Anaerobic Digestion Modeling and Optimization Using Nature-Inspired Techniques. Processes 2019, 7, 953. [CrossRef]

7. Ghanavati, H.; Nahvi, I.; Karimi, K. Organic fraction of municipal solid waste as a suitable feedstock for the production of lipid by oleaginous yeast Cryptococcus aerius. Waste Manag. 2015, 38, 141-148. [CrossRef] 
8. Gunes, B.; Stokes, J.; Davis, P.; Connolly, C.; Lawler, J. Pre-treatments to enhance biogas yield and quality from anaerobic digestion of whiskey distillery and brewery wastes: A review. Renew. Sustain. Energy Rev. 2019, 113, 109281. [CrossRef]

9. Akunna, J.C.; Clark, M. Performance of a granular-bed anaerobic baffled reactor (GRABBR) treating whisky distillery wastewater. Bioresour. Technol. 2000, 74, 257-261. [CrossRef]

10. Jáuregui-Jáuregui, J.A.; Méndez-Acosta, H.O.; González-Alvarez, V.; Snell-Castro, R.; Alcaraz-Gonzalez, V.; Godon, J.J. Anaerobic treatment of tequila vinasses under seasonal operating conditions: Start-up, normal operation and restart-up after a long stop and starvation period. Bioresour. Technol. 2014, 168, 33-40. [CrossRef]

11. Handous, N.; Gannoun, H.; Hamdi, M.; Bouallagui, H. Two-Stage Anaerobic Digestion of Meat Processing Solid Wastes: Methane Potential Improvement with Wastewater Addition and Solid Substrate Fermentation. Waste Biomass Valorization 2017, 10, 131-142. [CrossRef]

12. Chow, W.L.; Chong, S.; Lim, J.W.; Chan, Y.J.; Chong, M.; Tiong, T.J.; Chin, J.; Pan, G.-T. Anaerobic Co-Digestion of Wastewater Sludge: A Review of Potential Co-Substrates and Operating Factors for Improved Methane Yield. Processes 2020, 8, 39. [CrossRef]

13. Stams, A.J.M.; Plugge, C.; De Bok, F.; Van Houten, B.; Lens, P.N.L.; Dijkman, H.; Weijma, J. Metabolic interactions in methanogenic and sulfate-reducing bioreactors. Water Sci. Technol. 2005, 52, 13-20. [CrossRef]

14. Moraes, B.S.; Zaiat, M.; Bonomi, A. Anaerobic digestion of vinasse from sugarcane ethanol production in Brazil: Challenges and perspectives. Renew. Sustain. Energy Rev. 2015, 44, 888-903. [CrossRef]

15. Izumi, K.; Okishio, Y.-K.; Nagao, N.; Niwa, C.; Yamamoto, S.; Toda, T. Effects of particle size on anaerobic digestion of food waste. Int. Biodeterior. Biodegradation 2010, 64, 601-608. [CrossRef]

16. Deepanraj, B.; Sivasubramanian, V.; Jayaraj, S. Experimental and kinetic study on anaerobic digestion of food waste: The effect of total solids and pH. J. Renew. Sustain. Energy 2015, 7, 63104. [CrossRef]

17. Mackintosh, A.F.; Shin, T.; Yang, H.; Choe, K. Hydrothermal Polymerization Catalytic Process Effect of Various Organic Wastes on Reaction Time, Yield, and Temperature. Processes 2020, 8, 303. [CrossRef]

18. Fdez-Güelfo, L.A.; Álvarez-Gallego, C.; Sales Márquez, D.; Romero García, L.I. Biological pretreatment applied to industrial organic fraction of municipal solid wastes (OFMSW): Effect on anaerobic digestion. Chem. Eng. J. 2011, 172, 321-325. [CrossRef]

19. Bolado-Rodríguez, S.; Toquero, C.; Martín-Juárez, J.; Travaini, R.; Garcia-Encina, P.A.; Bolado, S. Effect of thermal, acid, alkaline and alkaline-peroxide pretreatments on the biochemical methane potential and kinetics of the anaerobic digestion of wheat straw and sugarcane bagasse. Bioresour. Technol. 2016, 201, 182-190. [CrossRef]

20. Jin, G.; Bierma, T. Low-heat alkaline pretreatment of biomass for dairy anaerobic codigestion. J. Environ. Sci. Heal. Part B Pesticides Food Contam. Agric. Wastes 2014, 49, 786-796. [CrossRef]

21. Khatri, S.; Wu, S.; Kizito, S.; Zhang, W.; Li, J.; Dong, R. Synergistic effect of alkaline pretreatment and Fe dosing on batch anaerobic digestion of maize straw. Appl. Energy 2015, 158, 55-64. [CrossRef]

22. Zhu, J.; Wan, C.; Li, Y. Enhanced solid-state anaerobic digestion of corn stover by alkaline pretreatment. Bioresour. Technol. 2010, 101, 7523-7528. [CrossRef] [PubMed]

23. Khadaroo, S.N.B.A.; Poh, P.E.; Gouwanda, D.; Grassia, P. Applicability of various pretreatment techniques to enhance the anaerobic digestion of Palm oil Mill effluent (POME): A review. J. Environ. Chem. Eng. 2019, 7, 103310. [CrossRef]

24. Chen, X.; Gu, Y.; Zhou, X.; Zhang, Y. Asparagus stem as a new lignocellulosic biomass feedstock for anaerobic digestion: Increasing hydrolysis rate, methane production and biodegradability by alkaline pretreatment. Bioresour. Technol. 2014, 164, 78-85. [CrossRef]

25. Tedesco, S.; Barroso, T.M.; Olabi, A.-G. Optimization of mechanical pre-treatment of Laminariaceae spp. biomass-derived biogas. Renew. Energy 2014, 62, 527-534. [CrossRef]

26. Agbor, V.B.; Cicek, N.; Sparling, R.; Berlin, A.; Levin, D.B. Biomass pretreatment: Fundamentals toward application. Biotechnol. Adv. 2011, 29, 675-685. [CrossRef]

27. Gao, J.; Chen, L.; Yuan, K.; Huang, H.; Yan, Z. Ionic liquid pretreatment to enhance the anaerobic digestion of lignocellulosic biomass. Bioresour. Technol. 2013, 150, 352-358. [CrossRef]

28. Pant, D.; Adholeya, A. Biological approaches for treatment of distillery wastewater: A review. Bioresour. Technol. 2007, 98, 2321-2334. [CrossRef] 
29. Sežun, M.; Zupančič, G.D.; Logar, R.M.; Grilc, V. Anaerobic Digestion of Brewery Spent Grain/: Inhibition by Phenolic Degradation Products. Acta Chim. Slov. 2011, 58, 158-166.

30. Mohana, S.; Acharya, B.K.; Madamwar, D. Distillery spent wash: Treatment technologies and potential applications. J. Hazard. Mater. 2009, 163, 12-25. [CrossRef]

31. Kim, J.; Park, C.; Kim, T.-H.; Lee, M.; Kim, S.; Kim, S.W.; Lee, J. Effects of various pretreatments for enhanced anaerobic digestion with waste activated sludge. J. Biosci. Bioeng. 2003, 95, 271-275. [CrossRef]

32. Carrère, H.; Dumas, C.; Battimelli, A.; Batstone, D.; Delgenes, J.P.; Steyer, J.; Ferrer, I. Pretreatment methods to improve sludge anaerobic degradability: A review. J. Hazard. Mater. 2010, 183, 1-15. [CrossRef]

33. Bayard, R.; Benbelkacem, H.; Gourdon, R.; Buffière, P. Characterization of selected municipal solid waste components to estimate their biodegradability. J. Environ. Manag. 2018, 216, 4-12. [CrossRef]

34. Esposito, G.; Frunzo, L.; Panico, A.; Pirozzi, F. Modelling the effect of the OLR and OFMSW particle size on the performances of an anaerobic co-digestion reactor. Process. Biochem. 2011, 46, 557-565. [CrossRef]

35. Le, T.M.; Vo, P.T.; Do, T.A.; Tran, L.T.; Truong, H.T.; Le, T.T.X.; Chen, Y.-H.; Chang, C.-C.; Chang, C.-Y.; Tran, Q.T.; et al. Effect of Assisted Ultrasonication and Ozone Pretreatments on Sludge Characteristics and Yield of Biogas Production. Processes 2019, 7, 743. [CrossRef]

36. Ariunbaatar, J.; Panico, A.; Esposito, G.; Pirozzi, F.; Lens, P.N.L. Pretreatment methods to enhance anaerobic digestion of organic solid waste. Appl. Energy 2014, 123, 143-156. [CrossRef]

37. Appels, L.; Baeyens, J.; Degreve, J.; Dewil, R. Principles and potential of the anaerobic digestion of waste-activated sludge. Prog. Energy Combust. Sci. 2008, 34, 755-781. [CrossRef]

38. Appels, L.; Degreve, J.; Van Der Bruggen, B.; Van Impe, J.F.M.; Dewil, R. Influence of low temperature thermal pre-treatment on sludge solubilisation, heavy metal release and anaerobic digestion. Bioresour. Technol. 2010, 101, 5743-5748. [CrossRef]

39. Liao, X.; Li, H.; Zhang, Y.; Liu, C.; Chen, Q. Accelerated high-solids anaerobic digestion of sewage sludge using low-temperature thermal pretreatment. Int. Biodeterior. Biodegradation 2016, 106, 141-149. [CrossRef]

40. Mottet, A.; Steyer, J.P.; Déléris, S.; Vedrenne, F.; Chauzy, J.; Carrère, H. Kinetics of thermophilic batch anaerobic digestion of thermal hydrolysed waste activated sludge. Biochem. Eng. J. 2009, 46, 169-175. [CrossRef]

41. Zhen, G.; Lu, X.; Kato, H.; Youcai, Z.; Li, Y.-Y. Overview of pretreatment strategies for enhancing sewage sludge disintegration and subsequent anaerobic digestion: Current advances, full-scale application and future perspectives. Renew. Sustain. Energy Rev. 2017, 69, 559-577. [CrossRef]

42. Mata-Alvarez, J.; Dosta, J.; Romero-Güiza, M.S.; Fonoll, X.; Peces, M.; Astals, S. A critical review on anaerobic co-digestion achievements between 2010 and 2013. Renew. Sustain. Energy Rev. 2014, 36, 412-427. [CrossRef]

43. Wang, K.; Yin, J.; Shen, D.; Li, N. Anaerobic digestion of food waste for volatile fatty acids (VFAs) production with different types of inoculum: Effect of pH. Bioresour. Technol. 2014, 161, 395-401. [CrossRef] [PubMed]

44. Ward, A.J.; Hobbs, P.J.; Holliman, P.J.; Jones, D.L. Optimisation of the anaerobic digestion of agricultural resources. Bioresour. Technol. 2008, 99, 7928-7940. [CrossRef]

45. Heiske, S.; Jurgutis, L.; Kádár, Z. Evaluation of Novel Inoculation Strategies for Solid State Anaerobic Digestion of Yam Peelings in Low-Tech Digesters. Energies 2015, 8, 1802-1816. [CrossRef]

46. Sluiter, A.; Hames, B.; Hyman, D.; Payne, C.; Ruiz, R.; Scarlata, C.; Sluiter, J.; Templeton, D.; Wolfe, J. Determination of Total Solids in Biomass and Total Dissolved Solids in Liquid Process Samples; National Renewable Energy Laboratory: Golden, CO, USA, 2008; Volume 9.

47. Van Soest, P.J.; Wine, R.H. Use of Detergents in the Analysis of Fibrous Feeds. IV. Determination of Plant Cell-Wall Constituents. J. Assoc. Off. Agric. Chem. Int. 1967, 50, 50-55. [CrossRef]

48. Van Soest, P.J. Use of Detergents in the Analysis of Fibrous Feeds. II. A Rapid Method for the Determination of Fiber and Lignin. J. Assoc. Off. Agric. Chem. Int. 1963, 46, 829-835. [CrossRef]

49. Tokuda, M.; Ohta, N.; Morimura, S.; Kida, K. Methane fermentation of pot ale from a whisky distillery after enzymatic or microbial treatment. J. Ferment. Bioeng. 1998, 85, 495-501. [CrossRef]

50. Meixner, K.; Fuchs, W.; Valkova, T.; Svardal, K.; Loderer, C.; Neureiter, M.; Bochmann, G.; Drosg, B. Effect of precipitating agents on centrifugation and ultrafiltration performance of thin stillage digestate. Sep. Purif. Technol. 2015, 145, 154-160. [CrossRef]

51. Kang, X.; Liu, Y. Chemically Enhanced Primary Sludge as an Anaerobic Co-Digestion Additive for Biogas Production from Food Waste. Processes 2019, 7, 709. [CrossRef] 
52. Tedesco, S.; Benyounis, K.Y.; Olabi, A.-G. Mechanical pretreatment effects on macroalgae-derived biogas production in co-digestion with sludge in Ireland. Energy 2013, 61, 27-33. [CrossRef]

53. Valero, D.; Montes, J.A.; Rico, J.L.; Rico, C. Influence of headspace pressure on methane production in Biochemical Methane Potential (BMP) tests. Waste Manag. 2016, 48, 193-198. [CrossRef] [PubMed]

54. Verein Deutscher Ingenieure (VDI). Fermentation of Organic Materials: Characterization of the Substrate, Sampling, Collection of Material Data, Fermentation Tests; VDI: Berlin, Germany, 2006.

55. Benyounis, K.Y.; Olabi, A.-G.; Hashmi, M.S.J. Effect of laser welding parameters on the heat input and weld-bead profile. J. Mater. Process. Technol. 2005, 164-165, 978-985. [CrossRef]

56. Eltawahni, H.A.; Olabi, A.-G.; Benyounis, K.Y. Investigating the $\mathrm{CO}_{2}$ laser cutting parameters of MDF wood composite material. Opt. Laser Technol. 2011, 43, 648-659. [CrossRef]

57. Ali, S.; Rani, A.A.; Mufti, R.A.; Ahmed, S.; Baig, Z.; Hastuty, S.; Razak, M.A.A.; Aliyu, A.A. Optimization of Sintering Parameters of 316L Stainless Steel for In-Situ Nitrogen Absorption and Surface Nitriding Using Response Surface Methodology. Processes 2020, 8, 297. [CrossRef]

58. Pandian, M.; Sivapirakasam, S.P.; Udayakumar, M. Investigation on the effect of injection system parameters on performance and emission characteristics of a twin cylinder compression ignition direct injection engine fuelled with pongamia biodiesel-diesel blend using response surface methodology. Appl. Energy 2011, 88, 2663-2676. [CrossRef]

59. Kazemi, P.; Steyer, J.-P.; Bengoa, C.; Capafons, J.F.; Giralt, J. Robust Data-Driven Soft Sensors for Online Monitoring of Volatile Fatty Acids in Anaerobic Digestion Processes. Processes 2020, 8, 67. [CrossRef]

60. Montgomery, D.C. Time Series Analysis and Forecasting; Springer: Cham, Switzerland, 2016. [CrossRef]

61. Goodwin, J.A.S.; Finlayson, J.M.; Low, E.W. A further study of the anaerobic biotreatment of malt whisky distillery pot ale using an UASB system. Bioresour. Technol. 2001, 78, 155-160. [CrossRef]

62. Sankaran, K.; Premalatha, M.; Vijayasekaran, M.; Somasundaram, V.T. DEPHY project: Distillery wastewater treatment through anaerobic digestion and phycoremediation-A green industrial approach. Renew. Sustain. Energy Rev. 2014, 37, 634-643. [CrossRef]

63. Uzal, N.; Gökçay, C.F.; Demirer, G.N. Sequential (anaerobic/aerobic) biological treatment of malt whisky wastewater. Process. Biochem. 2003, 39, 279-286. [CrossRef]

64. Graham, J.; Peter, B.; Walker, G.M.; Wardlaw, A.; Campbell, E. Characterisation of the Pot ale Profile from a Malt Whisky Distillery; Nottingham University Press/The Institute of Brewing and Distilling: Nottingham, UK, 2012; Volume 43, pp. 1-7.

65. Goodwin, J.A.S.; Stuart, J.B. Anaerobic digestion of malt whisky distillery pot ale using upflow anaerobic sludge blanket reactors. Bioresour. Technol. 1994, 49, 75-81. [CrossRef]

66. Kida, K.; Morimura, S.; Mochinaga, Y.; Tokuda, M. Efficient removal of organic matter and NH4+ from pot ale by a combination of methane fermentation and biological denitrification and nitrification processes. Process. Biochem. 1999, 34, 567-575. [CrossRef]

67. Mallick, P.; Akunna, J.C.; Walker, G.M. Anaerobic digestion of distillery spent wash: Influence of enzymatic pre-treatment of intact yeast cells. Bioresour. Technol. 2010, 101, 1681-1685. [CrossRef]

68. Dionisi, D.; Bruce, S.S.; Barraclough, M.J. Effect of pH adjustment, solid-liquid separation and chitosan adsorption on pollutants' removal from pot ale wastewaters. J. Environ. Chem. Eng. 2014, 2, 1929-1936. [CrossRef]

69. Ansa-Asare, O.D.; Marr, I.L.; Cresser, M.S. Evaluation of modelled and measured patterns of dissolved oxygen in a freshwater lake as an indicator of the presence of biodegradable organic pollution. Water Res. 2000, 34, 1079-1088. [CrossRef]

70. Barrena, R.; Traub, J.E.; Gil, C.R.; Goodwin, J.A.; Harper, A.J.; Willoughby, N.A.; Sánchez, A.; Aspray, T.J. Batch anaerobic digestion of deproteinated malt whisky pot ale using different source inocula. Waste Manag. 2018, 71, 675-682. [CrossRef]

(C) 2020 by the authors. Licensee MDPI, Basel, Switzerland. This article is an open access article distributed under the terms and conditions of the Creative Commons Attribution (CC BY) license (http://creativecommons.org/licenses/by/4.0/). 